\title{
Recombinant Human Deoxyribonuclease I
}

\author{
Robert A. Lazarus and Jeffrey S. Wagenert
}

\section{INTRODUCTION}

Human deoxyribonuclease I (DNase I) is an endonuclease that catalyzes the hydrolysis of extracellular DNA and is just one of the numerous types of nucleases found in nature (Horton 2008; Yang 2011). It is the most extensively studied member in the family of DNase I-like nucleases (Keyel 2017; Lazarus 2002; Baranovskii et al. 2004; Shiokawa and Tanuma 2001); the homologous bovine DNase I has received even greater attention historically (Laskowski 1971; Moore 1981; Chen and Liao 2006). Mammalian DNases have been broadly divided into several families initially based upon their products, $\mathrm{pH}$ optima, and divalent metal ion requirements. These include the neutral DNase I family (EC 3.1.21.1), the acidic DNase II family (EC 3.1.22.1), as well as apoptotic nucleases such as DFF40/CAD and endonuclease G (Keyel 2017; Lazarus 2002; Evans and Aguilera 2003; Widlak and Garrard 2005). The human DNase I gene resides on chromosome 16p13.3 and contains 10 exons and 9 introns, which span $15 \mathrm{~kb}$ of genomic DNA (Kominato et al. 2006). DNase I is synthesized as a precursor and contains a 22-residue signal sequence that is cleaved upon secretion, resulting in the 260-residue mature enzyme. It is secreted by the pancreas and parotid glands, consistent with its proposed primary role of digesting nucleic acids in the gastrointestinal tract. However, it is also present in blood and urine as well as other tissues, suggesting additional functions.

Recombinant human DNase I (rhDNase I, rhDNase, Pulmozyme ${ }^{\circledast}$, dornase alfa) has been developed

This chapter is dedicated in honor of a lifetime of scientific and clinical contributions by Jeffrey S. Wagener, deceased October 24, 2018.

R. A. Lazarus $(\square)$

Department of Early Discovery Biochemistry, Genentech Inc., South San Francisco, CA, USA

e-mail: lazarus.bob@gene.com

\section{J. S. Wagener}

Department of Pediatrics, University of Colorado School

of Medicine, Aurora, CO, USA clinically where it is aerosolized into the airways for treatment of pulmonary disease in patients with cystic fibrosis (CF) (Suri 2005; Wagener and Kupfer 2012). Cystic fibrosis is an autosomal recessive disease caused by mutations in the CF transmembrane conductance regulator (CFTR) gene (Kerem et al. 1989; Riordan et al. 1989). Mutations of this gene result in both abnormal quantity and function of an apical membrane protein responsible for chloride ion transfer. The CFTR protein is a member of the ATP-binding cassette transporter superfamily (member ABCC7) and in addition to transporting chloride has many other functions including the regulation of epithelial sodium channels, ATP-release mechanisms, anion exchangers, sodium bicarbonate transporters, and aquaporin water channels found in airways, intestine, pancreas, sweat duct, and other fluid-transporting tissues (Guggino and Stanton 2006). Clinical manifestations of the disease include chronic obstructive airway disease, increased sweat electrolyte excretion, male infertility due to obstruction of the vas deferens, and exocrine pancreatic insufficiency.

In the airways, abnormal CFTR results in altered secretions and mucociliary clearance, leading to a cycle of obstruction, chronic bacterial infection, and neutrophildominated inflammation. This bacterial infection and neutrophil-dominated airway inflammation begins early in the patient's life and, while initially it helps to control infection, the degree of inflammation remains excessive to the degree of infection. Poorly regulated neutrophildominated inflammation damages the airways over time due to the release of potent oxidants and proteases. Additionally, necrosis of neutrophils leads to the accumulation of extracellular DNA and actin, increasing the viscosity of mucous and creating further obstruction, and a downward spiral of lung damage, loss of lung function, and ultimately premature death (Fig. 22.1).

rhDNase I has also been studied in a variety of other diseases where extracellular DNA has been postulated to play a pathological role, including prolonged mechanical ventilation due to persistent airway obstruction (Riethmueller et al. 2006), 


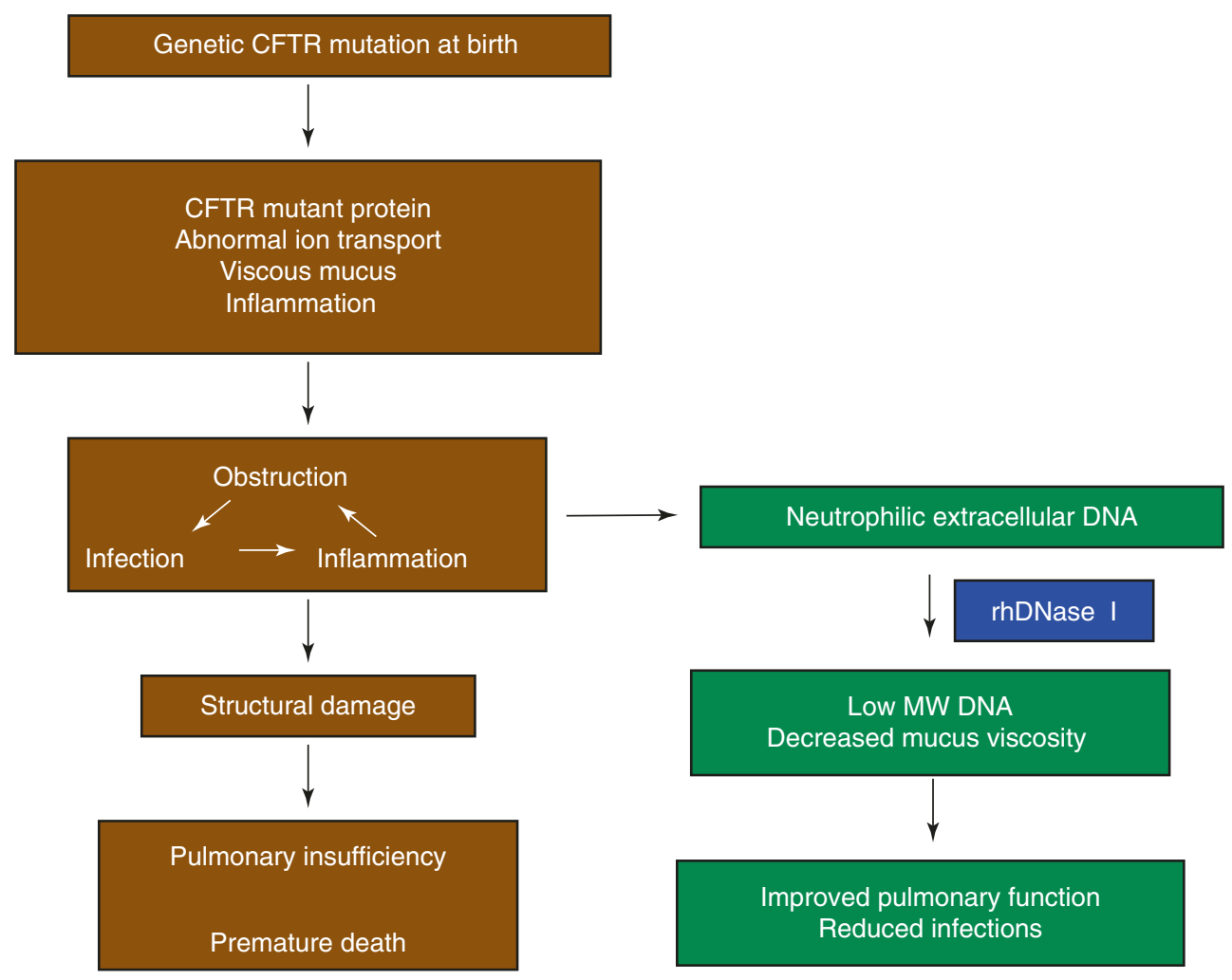

Figure 22.1 Cystic fibrosis and rhDNase I. CFTR genetic mutation at birth leads to either reduced or improperly folded CFTR protein, which results in altered ion transport, viscous mucus, and inflammation in the airways. Eventually, this leads to obstruction of the airways, bacterial infection, and further inflammation. After neutrophils arrive to fight the infection, they die and release cellular contents, one of which is DNA. Persistent obstruction, infection, and inflammation leads to structural damage and eventually pulmonary insufficiency and premature death. rhDNase I is aerosolized into the airways where it degrades DNA to lower molecular weight fragments, thus reducing CF mucus viscosity and allowing expectoration, which improves lung function and reduces bacterial infections

ventilator-associated pneumonia in infants (Scala et al. 2017), atelectasis (Hendriks et al. 2005), chronic sinusitis (Cimmino et al. 2005), primary ciliary dyskinesia (Desai et al. 1995; ten Berge et al. 1999; El Abiad et al. 2007), other non-CF lung diseases in children (Boogaard et al. 2007a), and empyema (Simpson et al. 2003; Rahman et al. 2011). rhDNase I has also been studied to examine its effectiveness in the presence or absence of antibiotics against biofilm producing strains of Staphylococcus aureus and Staphylococcus epidermidis (Kaplan et al. 2012). rhDNase I exhibits potent antibiofilm and antimicrobial-sensitizing activities at clinically achievable concentrations.

Finally, the use of rhDNase I has been investigated in systemic lupus erythematosus (SLE) where degradation or prevention of immune complexes containing anti-DNA antigens may have therapeutic benefit (Lachmann 2003; Davis et al. 1999).

\section{Historical Perspective and Rationale}

Macromolecules that contribute to the physical properties of lung secretions include mucus glycoproteins, filamentous actin, and DNA. Experiments in the 1950s and 1960s revealed that DNA is present in very high concentrations (3-14 $\mathrm{mg} / \mathrm{mL}$ ) only in infected lung secretions (Matthews et al. 1963). This implied that the DNA that contributes to the high viscoelastic nature of CF sputum is derived from neutrophils responding to chronic infections (Potter et al. 1969). These DNA-rich secretions also bind aminoglycoside antibiotics commonly used for treatment of pulmonary infections and thus may reduce their efficacy (Ramphal et al. 1988; Bataillon et al. 1992).

Early in vitro studies in which lung secretions were incubated for several hours with partially purified bovine pancreatic DNase I showed a large reduction in viscosity (Armstrong and White 1950; Chernick et al. 1961). Based on these observations, bovine pancreatic DNase I (dornavac or pancreatic dornase) was approved in the United States for human use in 1958. Numerous uncontrolled clinical studies in patients with pneumonia and one study in patients with CF suggested that bovine pancreatic DNase I was effective in reducing the viscosity of lung secretions (Lieberman 1968). However, severe adverse reactions occurred occasionally, perhaps 
due to allergic reactions to a foreign protein or from contaminating proteases, since up to $2 \%$ of trypsin and chymotrypsin were present in the final product (Raskin 1968; Lieberman 1962). Both bovine DNase I products were eventually withdrawn from the market.

In the late 1980s, human deoxyribonuclease I was cloned from a human pancreatic cDNA library, sequenced and expressed recombinantly using mammalian cell culture in Chinese hamster ovary $(\mathrm{CHO})$ cells to reevaluate the potential of DNase I as a therapeutic for cystic fibrosis (Shak et al. 1990). In vitro incubation of purulent sputum from CF patients with catalytic concentrations of rhDNase I reduced its viscoelasticity (Shak et al. 1990). The reduction in viscoelasticity was directly related to both rhDNase I concentration and reduction in the size of the DNA in the samples. Therefore, reduction of high molecular weight DNA into smaller fragments by treatment with aerosolized rhDNase I was proposed as a mechanism to reduce the mucus viscosity and improve mucus clearability from obstructed airways in patients. It was hoped that improved clearance of the purulent mucus would enhance pulmonary function and reduce recurrent exacerbations of respiratory symptoms requiring parenteral antibiotics. This proved to be the case and rhDNase I was approved by the Food and Drug Administration in 1993. Since that time the clinical use of rhDNase I has continued to increase with over $67 \%$ of $\mathrm{CF}$ patients receiving chronic therapy (Konstan et al. 2010).

\section{PROTEIN CHEMISTRY, ENZYMOLOGY, AND STRUCTURE}

The protein chemistry of human DNases including DNase I has been reviewed (Lazarus 2002; Baranovskii et al. 2004). Recombinant human DNase I is a monomeric, 260-amino acid glycoprotein (Fig. 22.2) produced by mammalian $\mathrm{CHO}$ cells (Shak et al. 1990). The protein has four cysteines, which are oxidized into two disulfides between Cys101Cys104 and Cys173-Cys209 as well as two potential N-linked glycosylation sites at Asn18 and Asn106 (Fig. 22.2). rhDNase I is glycosylated at both sites and migrates as a broad band on polyacrylamide gel electrophoresis gels with an approximate molecular weight of $37 \mathrm{kDa}$, which is significantly higher than the predicted molecular mass from the amino acid sequence of $29.3 \mathrm{kDa}$. rhDNase I is an acidic protein and has a calculated $\mathrm{pI}$ of 4.58 . The primary amino acid sequence is identical to that of the native human enzyme purified from urine.

DNase I cleaves double-stranded DNA, and to a much lesser degree single-stranded DNA, nonspecifically by nicking phosphodiester linkages in one of the strands between the 3 -oxygen atom and the phosphorus to yield 3'-hydroxyl and 5'-phosphoryl oligonucleotides with inversion of configuration at the phosphorus. rhDNase I enzymatic activity is dependent upon the presence of divalent metal ions for structure, as there are two tightly bound $\mathrm{Ca}^{2+}$ atoms and catalysis, which requires either $\mathrm{Mg}^{2+}$ or $\mathrm{Mn}^{2+}$ (Pan and Lazarus 1999). The active site includes two histidine

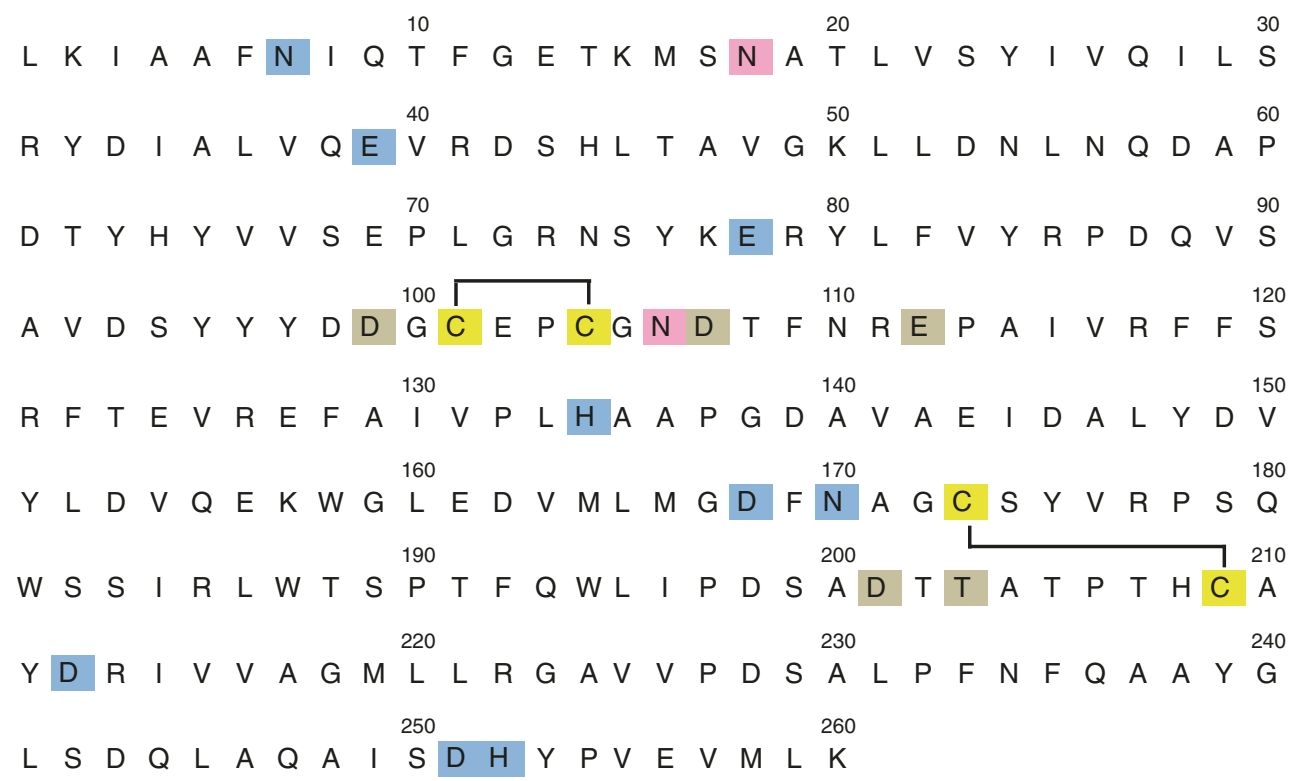

Figure 22.2 Primary amino acid sequence of rhDNase I. Active site residues are highlighted in blue, cysteine residues that form disulfide bonds are shown in yellow, $\mathrm{N}$-linked glycosylation sites are highlighted in pink, and residues involved in Ca ${ }^{2+}$ coordination are shown in beige. The 22-residue signal sequence that is cleaved prior to secretion is not shown 
residues (His134 and His252) and two acidic residues (Glu78 and Asp 212), all of which are critical for the general acid-base catalysis of phosphodiester bonds since alanine substitution of any of these results in a total loss of activity (Ulmer et al. 1996). Other residues involved in the coordination of divalent metal ions at the active site and DNA contact residues have also been identified by mutational analysis and include Asn7, Glu39, Asp168, Asn170, and Asp251 (Pan et al. 1998a; Parsiegla et al. 2012). The two $\mathrm{Ca}^{2+}$ binding sites require acidic or polar residues for coordination of $\mathrm{Ca}^{2+}$; for site 1 these include Asp201 and Thr203 and for site 2 these include Asp99, Asp107, and Glu112 (Pan and Lazarus 1999). DNase I is a relatively stable enzyme and shows optimal activity at $\mathrm{pH}$ 5.5-7.5. It is inactivated by heat and is potently inhibited by EDTA and G-actin. Surprisingly, DNase I is also inhibited by $\mathrm{NaCl}$ and has only ca. $30 \%$ of the maximal activity in physiological saline.

rhDNase I belongs to the DNase I-like structural superfamily according to SCOP and is also related to the endonuclease-exonuclease-phosphatase family (Andreeva et al. 2008; Dlakic 2000; Wang et al. 2010). The X-ray crystal structure of rhDNase I was initially solved at $2.2 \AA$ resolution and superimposes with the biochemically more widely studied bovine DNase I, which shares $78 \%$ sequence identity, with an rms deviation for main chain atoms of $0.56 \AA$ (Wolf et al. 1995). DNase I is a compact $\alpha / \beta$ protein having a core of two tightly packed six-stranded $\beta$-sheets surrounded by eight $\alpha$-helices and several loop regions (Fig. 22.3). Bovine DNase I has also been crystallized in complex with G-actin (Kabsch et al. 1990) as well as with several short oligonucleotides, revealing key features of DNA recognition in the minor groove and catalytic hydrolysis (Suck 1994).

More recently, the structure of rhDNase I containing a divalent $\mathrm{Mg}^{2+}$ and a phosphate in the active site has been solved at 1.95 A resolution (Parsiegla et al. 2012). The combined structural and mutagenesis data suggest a $\mathrm{Mg}^{2+}$-assisted pentavalent phosphate transition state during catalysis of rhDNase I, where Asp168 may play a key role as a catalytic general base. Asn170 is also in close proximity to both the attacking water molecule and the phosphoryl oxygen. His134 and His252 appear to act as general acids in stabilizing the pentavalent transition state. There is also a critical catalytic role for rhDNase I Asn7, a residue that is highly conserved among mammalian DNase I enzymes and members of the DNase I-like superfamily. The $\mathrm{Mg}^{2+}$ cation resides at the computationally predicted site IVb (Gueroult et al. 2010) and interacts with Asn7, Glu39, and Asp251 via a complex set of water-mediated hydrogen bond interactions. A comprehensive analysis of the rhDNase I

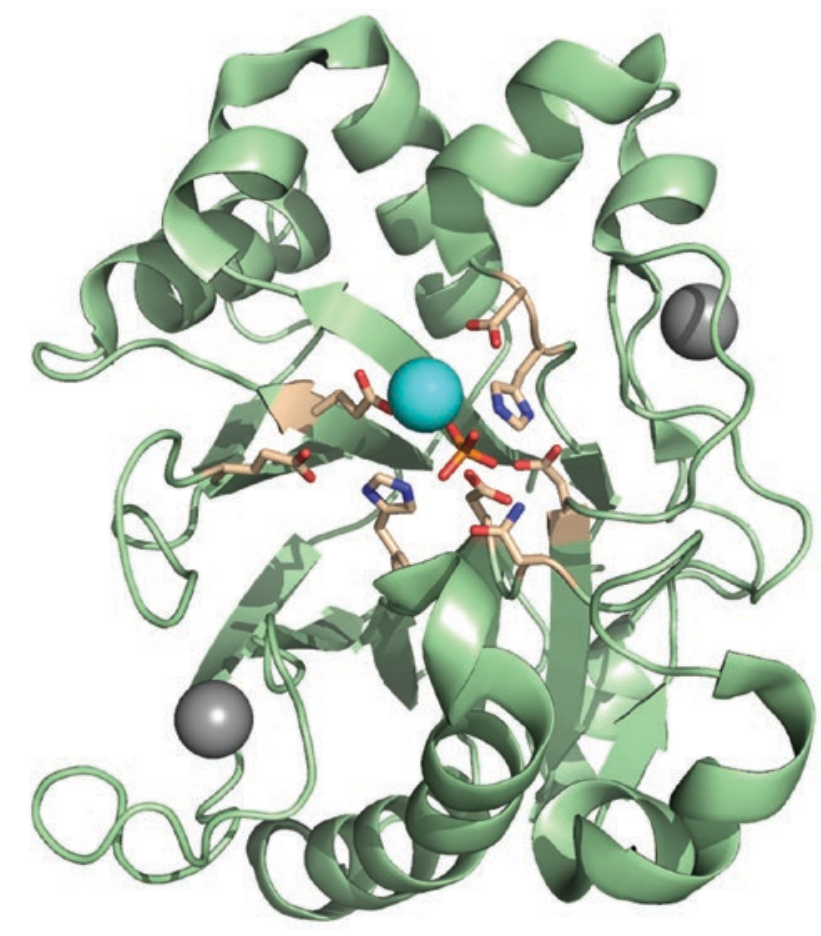

Figure 22.3 Cartoon representation of rhDNase I depicting the active site of the enzyme. The active site residues are shown as beige sticks where oxygen and nitrogen atoms are in red and blue, respectively. The $\mathrm{Mg}^{2+}$ ion is shown as a cyan sphere and $\mathrm{Ca}^{2+}$ ions are shown as grey spheres. The phosphate ion is shown in sticks with the phosphorus atom in orange. The figure was made using PyMOL (www.pymol.org) using accession code 4AWN for rhDNase I (Parsiegla et al. 2012)

with members of the DNase I-like structural superfamily (Andreeva et al. 2008; Dlakic 2000) such as the apurinic/apyrimidinic endonucleases from human (APE1) (Mol et al. 2000) and Neisseria meningitidis (Nape) (Carpenter et al. 2007), sphingomyelin phosphodiesterase (SMase) from Bacillus cereus (Ago et al. 2006), or the C-terminal domain of human CNOT6L nuclease (Wang et al. 2010) solved in complex with cations or DNA have revealed new insights into the catalytic mechanism of DNA hydrolysis.

Several variants of rhDNase I with greatly improved enzymatic properties have been engineered by site-directed mutagenesis (Pan and Lazarus 1997; Pan et al. 1998a). The methods for production of the variants and the assays to characterize them have been reviewed recently (Pan et al. 2001; Sinicropi and Lazarus 2001). The rationale for improving activity was to increase binding affinity to DNA by introducing positively charged residues (Arg or Lys) on rhDNase I loops at the DNA binding interface to form a salt bridge with phosphates on the DNA backbone. These so-called "hyperactive" rhDNase I variants are substantially more active than wild-type rhDNase I and are no longer 
inhibited by physiological saline. The greater catalytic activity of the hyperactive variants is due to a change in the catalytic mechanism from a "single nicking" activity in the case of wild-type rhDNase I to a "processive nicking" activity in the hyperactive rhDNase I variants (Pan and Lazarus 1997), where gaps rather than nicks result in a higher frequency of double strand cleavages.

It is interesting to note that significantly greater activity can result from just a few mutations on the surface that are not important for structural integrity. For whatever reason DNase I is not as efficient an enzyme as it could be for degrading DNA into small fragments. Furthermore the inhibition by G-actin can be eliminated by a single amino acid substitution (see below). Thus, DNase I is under some degree of regulation in vivo. One can only speculate that nature may have wanted to avoid an enzyme with too much DNA degrading activity that could result in undesired mutations in the genome.

\section{EMERGING BIOLOGY}

\section{Neutrophil Extracellular Traps}

Neutrophils are important effector cells that play a key role in innate immunity. They have well documented 'first-line defense' roles in phagocytosis of foreign organisms such as bacteria and fungi. NETosis, the formation and release of neutrophil extracellular traps (NETs) is another defense mechanism that has emerged more recently (Brinkmann et al. 2004). Neutrophils can degranulate, releasing NETs, which are structures of DNA filaments coated with toxic histones, proteases, oxidative enzymes and other proteins that can immobilize and neutralize bacteria in the extracellular environment. NETosis can lead to a cell death process that is distinct from both apoptosis and necrosis, but it can also be independent of cell death (Jorch and Kubes 2017; Honda and Kubes 2018). NETs and NETosis have been broadly studied in biology and their role in a wide variety of diseases is of great interest (Jorch and Kubes 2017; Brinkmann 2018). These have included autoimmune, inflammatory, thrombotic, cancer and other diseases such as SLE, vasculitis, acute pancreatitus, rheumatoid arthritis, Type 1 diabetes mellitus and wound healing, gout, inflammatory bowel disease; vascular occlusion, sepsis, ARDS, metastasis and others (Cools-Lartigue et al. 2014; Martinod and Wagner 2014; Merza et al. 2015; Wong et al. 2015; Lood et al. 2016; Park et al. 2016; Gupta and Kaplan 2016; JiménezAlcázar et al. 2017b; Apel et al. 2018; Honda and Kubes 2018). It is particularly significant that DNase I or rhDNase I was almost always used in the biological studies on the above mentioned disease areas to show the effect of NET degradation, most often resulting in beneficial effects. Notably, serum DNase I had been shown to be essential for degradation of NETs (Hakkim et al. 2010); however, other DNase I like nucleases like DNase 1L3 can also degrade NETs (Jiménez-Alcázar et al. 2017b).

While it is clear that NETs and NETosis plays an important role in biology, that role is quite complex. In many cases they likely play a beneficial role, however in others they may play a pathological role. Like many areas of biology and disease, it is likely the right balance as well as the their locality that makes the difference. Furthermore, it is not always clear if they are the cause or result of a given pathology; there is evidence supporting both in thrombosis (Jiménez-Alcázar et al. 2017a). There is much evidence showing that diseases involve a multitude of pathways. For example, there are strong connections between coagulation, inflammation and cancer pathways. It is not surprising that NETs also have connections with these pathways. NETosis is a factor in tumor progression as well as cancer associated thrombosis (Demers and Wagner 2014). Both neutrophils and circulating extracellular DNA have been suggested to play an important role in cancer (Hawes et al. 2015).

With respect to rhDNase I, it is especially noteworthy that NETs play a significant role in CF (Gray et al. 2015; Law and Gray 2017), since this is the major use of rhDNase I clinically. While rhDNase I has a rheological effect in reducing the viscoelasticity in CF sputum, it also has biological effects related to releasing various enzymes and proteins from the NETs upon hydrolysis of the DNA. In the CF lung, NETs may play less of a role as an antibacterial and more of a role in fostering inflammation. rhDNase I likely exerts its antiinflammatory function due to degradation of NETs.

\section{PHARMACOLOGY}

\section{In Vitro Activity in CF Sputum}

In vitro, rhDNase I hydrolyzes the DNA in sputum of CF patients and reduces sputum viscoelasticity (Shak et al. 1990). Effects of rhDNase I were initially examined using a relatively crude "pourability" assay. Pourability was assessed qualitatively by inverting a tube of sputum and observing the movement of sputum after a tap on the side of the tube. Catalytic amounts of rhDNase I $(50 \mu \mathrm{g} / \mathrm{mL})$ greatly reduced the viscosity of the sputum, rapidly transforming it from a viscous gel to a flowing liquid. More than $50 \%$ of the sputum moved down the tube within 15 min of incubation, and all the sputum moved freely down the tube within $30 \mathrm{~min}$. The qualitative results of the pourability assay were confirmed by quantitative measurement of viscosity using a Brookfield Cone-Plate viscometer (Fig. 22.4). The reduction of viscosity by rhDNase I is rhDNase I concentration-dependent and is associated with reduction in size of sputum DNA as measured by agarose gel electrophoresis (Fig. 22.5). 


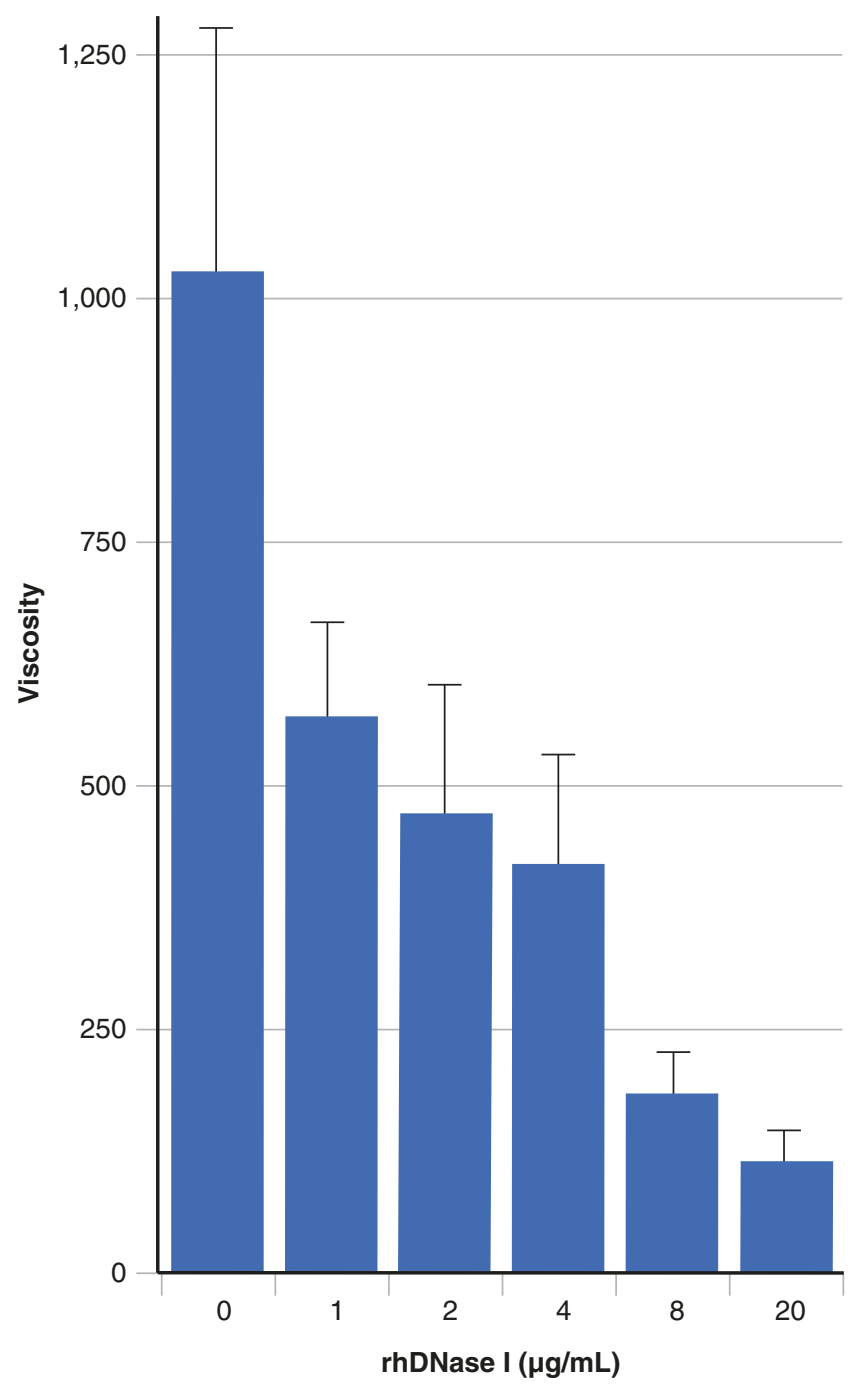

Figure 22.4 In vitro reduction in viscosity (in centipoise) of cystic fibrosis sputum by cone-plate viscometry. Cystic fibrosis sputum was incubated with various concentrations of rhDNase I of $15 \mathrm{~min}$ at $37^{\circ} \mathrm{C}$

Additional in vitro studies of CF mucus samples treated with rhDNase I demonstrated a dosedependent improvement in cough transport and mucociliary transport of CF mucus using a frog palate model and a reduction in adhesiveness as measured by mucus contact angle (Zahm et al. 1995). The improvements in mucus transport properties and adhesiveness were associated with a decrease in mucus viscosity and mucus surface tension, suggesting rhDNase I treatment may improve the clearance of mucus from airways. The in vitro viscoelastic properties of rhDNase I have also been studied in combination with normal saline, $3 \%$ hypertonic saline, or nacystelyn, the L-lysine salt of $\mathrm{N}$-acetyl cysteine (King et al. 1997; Dasgupta and King 1996). The major impact of rhDNase I on CF sputum is to decrease spinnabil-

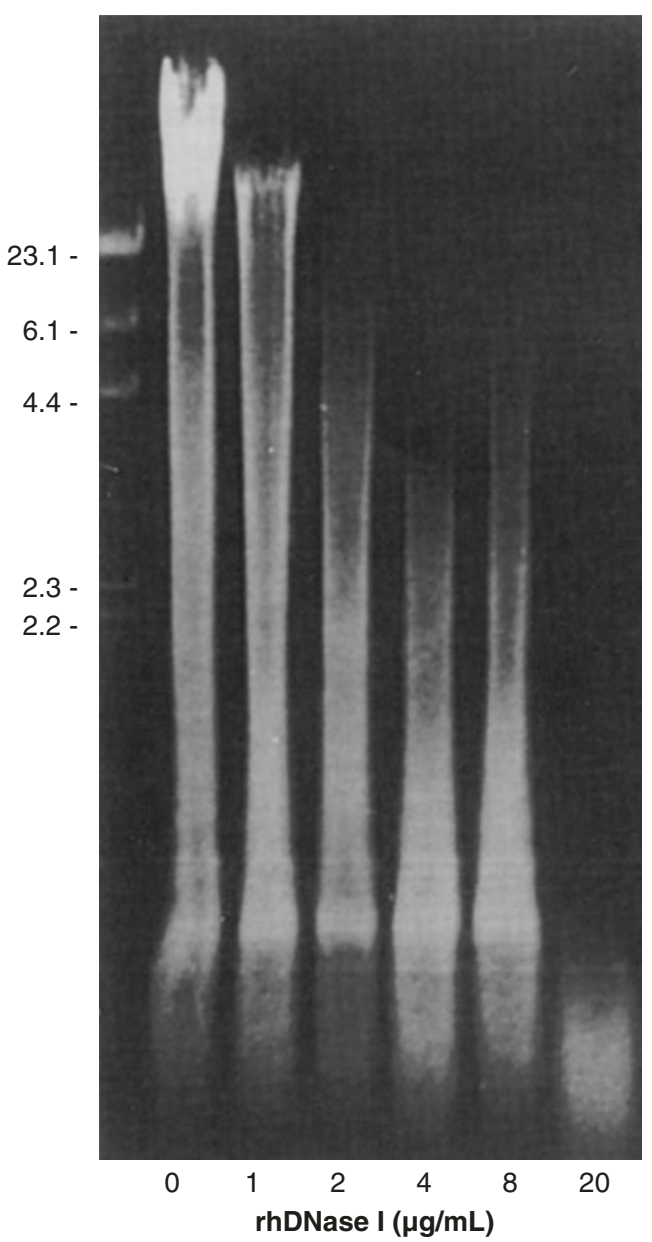

Figure 22.5 In vitro reduction in sputum DNA size as measured by agarose gel electrophoresis. Cystic fibrosis sputum was incubated with increasing concentrations $(0-20 \mu \mathrm{g} / \mathrm{mL})$ of rhDNase I for $150 \mathrm{~min}$ at $37^{\circ} \mathrm{C}$. Molecular weight standards for DNA in $\mathrm{kb}$ are indicated

ity, which is the thread forming ability of mucus under the influence of low amplitude stretching. CF sputum spinnability decreases $25 \%$ after 30 min incubation with rhDNase I (King et al. 1997). rhDNase I in normal saline and saline alone both increased the cough clearability index. With the combination of rhDNase I and 3\% hypertonic saline, there was minimal effect on spinnability however mucus rigidity and cough clearability improved greater than with either agent alone. The predicted mucociliary clearance did not significantly increase with 3\% saline either alone or in combination with rhDNase I. Combining rhDNase I with nacystelyn has an additive benefit on spinnability, but no effect on mucus rigidity or cough clearability (Dasgupta and King 1996). These effects of rhDNase I can be variable in vivo and do not necessarily correlate with the level of DNA in sputum. For example, 
sputum from CF patients that clinically responded to rhDNase I contains significantly higher levels of magnesium ions compared with sputum from patients who do not have a clear response (Sanders et al. 2006). Although this response is consistent with the requirement for divalent cations and their mode of action on DNase I (Campbell and Jackson 1980), the mechanism of increased rhDNase I activity by magnesium ions has been attributed to altering the polymerization state of actin such that equilibrium favors increased F-actin and decreased G-actin (see below).

The mechanism of action of rhDNase I to reduce CF sputum viscosity has been ascribed to DNA hydrolysis (Shak et al. 1990). However, an alternative mechanism involving depolymerization of filamentous actin (F-actin) has been suggested since F-actin contributes to the viscoelastic properties of CF sputum and the actin-depolymerizing protein gelsolin also reduces sputum viscoelasticity (Vasconcellos et al. 1994). F-actin is in equilibrium with its monomeric form (G-actin), which binds to rhDNase I with high affinity and is also a potent inhibitor of DNase I activity (Lazarides and Lindberg 1974). DNase I is known to depolymerize F-actin by binding to G-actin with high affinity, shifting the equilibrium in favor of rhDNase I/G-actin complexes (Hitchcock et al. 1976). To elucidate the mechanism of rhDNase I in CF sputum, the activity of two types of rhDNase I variants were compared in CF sputum (Ulmer et al. 1996). Active site variants were engineered that were unable to catalyze DNA hydrolysis but retained wild-type G-actin binding. Actinresistant variants that no longer bound G-actin but retained wild-type DNA hydrolytic activity were also characterized. The active site variants did not degrade DNA in CF sputum and did not decrease sputum viscoelasticity (Fig. 22.6). Since the active site variants retained the ability to bind G-actin, these results argue against depolymerization of F-actin as the mechanism of action. In contrast, the actin-resistant variants were more potent than wild-type DNase I in their ability to degrade DNA and reduce sputum viscoelasticity (Fig. 22.6). The increased potency of the actin-resistant variants indicated that G-actin was a significant inhibitor of wild-type DNase I in CF sputum and confirmed that hydrolysis of DNA was the mechanism by which rhDNase I decreases sputum viscoelasticity. The mechanism for reduction of sputum viscosity by gelsolin was subsequently determined to result from an unexpected second binding site on actin that competes with DNase I, thus relieving the inhibition by G-actin (Davoodian et al. 1997). Additional in vitro studies characterizing the relative potency of actin-resistant

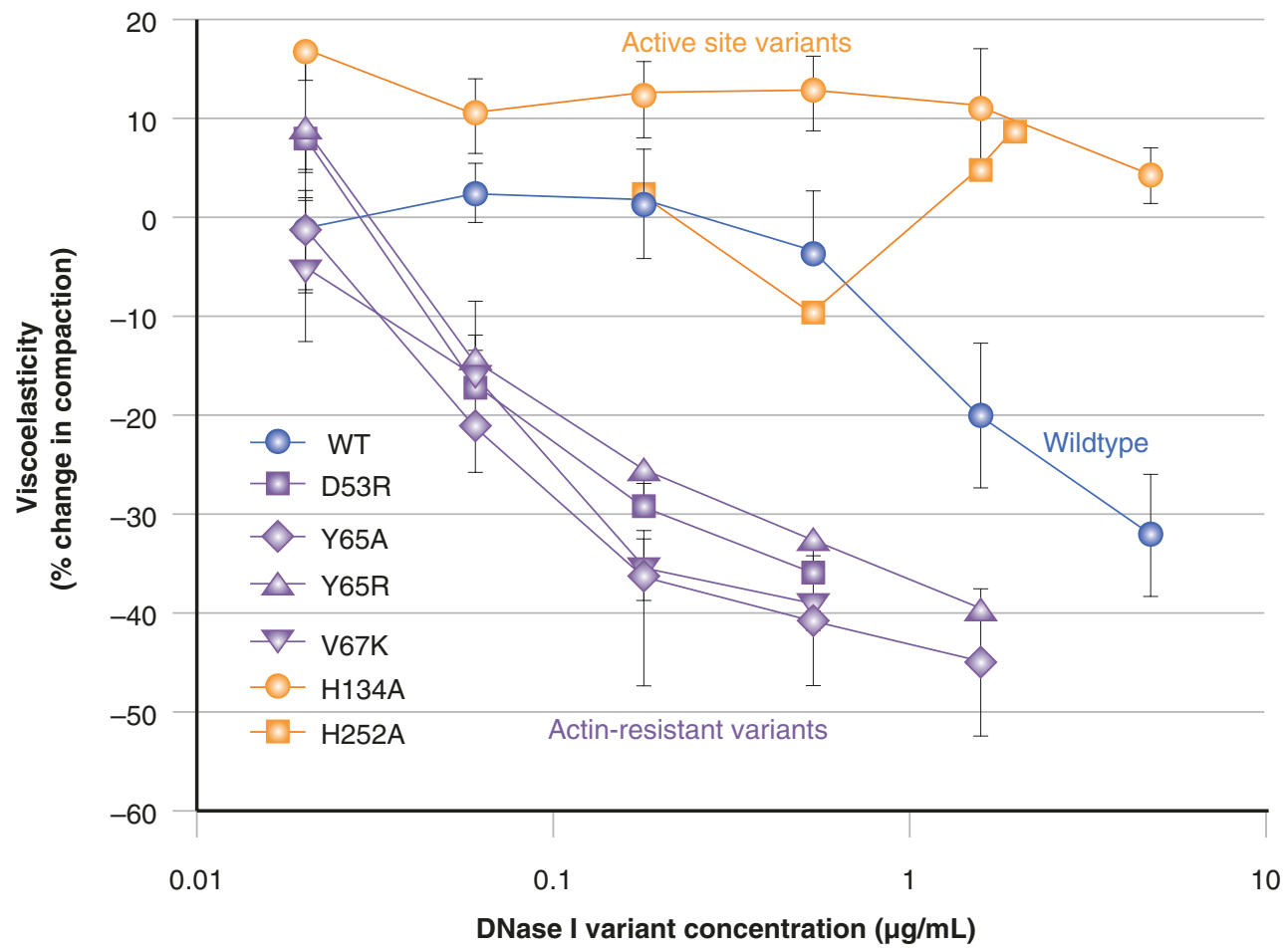

Figure 22.6 Mechanism of action in CF mucus for rhDNase I. The change in viscoelasticity in CF mucus as a function of DNase I concentration was determined for wild-type rhDNase I, two active site variants that no longer catalyze DNA hydrolysis and four variants that are no longer inhibited by G-actin (Ulmer et al. 1996) 


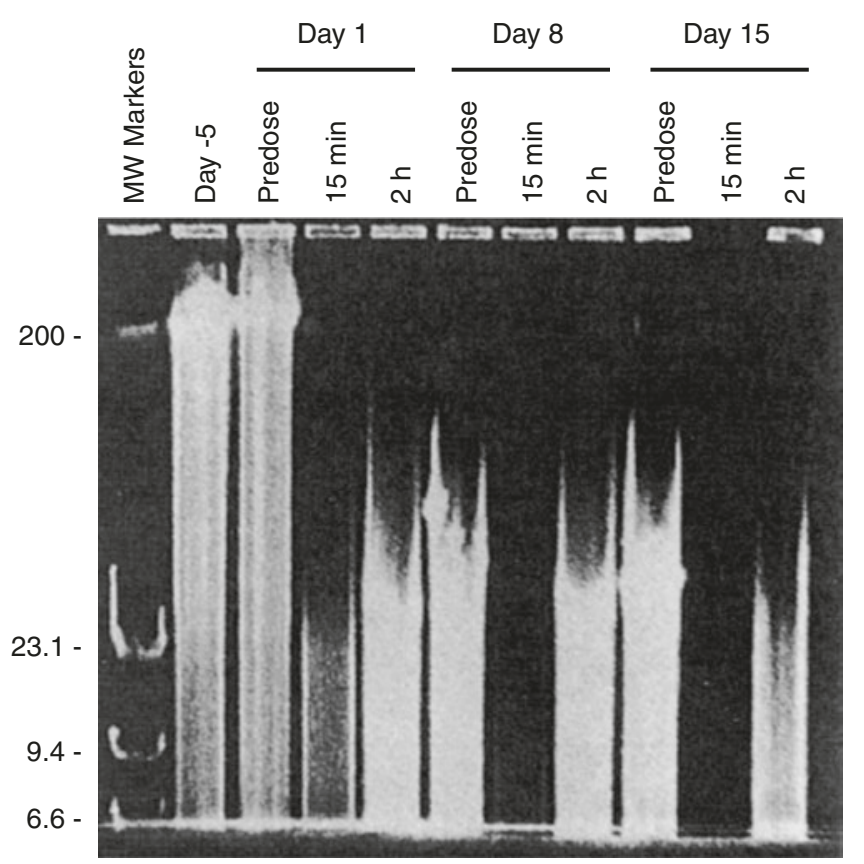

Figure $22.7 \square$ Sustained reduction in DNA length in sputum recovered from a CF patient treated with $2.5 \mathrm{mg}$ rhDNase I BID for up to 15 days. Samples were analyzed by pulsed field agarose gel electrophoresis. Molecular weight standards for DNA in kb are indicated

and hyperactive rhDNase I variants in serum and CF sputum have been reported (Pan et al. 1998b).

\section{- In Vivo Activity in CF Sputum}

In vivo confirmation of the proposed mechanism of action for rhDNase I has been obtained from direct characterization of apparent DNA size (Fig. 22.7) and measurements of enzymatic and immunoreactive (ELISA) activity of rhDNase I (Fig. 22.8) in sputum from cystic fibrosis patients (Sinicropi et al. 1994a). Sputum samples were obtained 1-6 h post-dose from adult cystic fibrosis patients after inhalation of 5-20 mg of rhDNase I. rhDNase I therapy produced a sustained reduction in DNA size in recovered sputum (Fig. 22.7), in good agreement with the in vitro data.

Inhalation of the therapeutic dose of rhDNase I produced sputum levels of rhDNase I which have been shown to be effective in vitro (Fig. 22.8) (Shak 1995). Similarly, delivery to CF patients as young as 3 months can produce bronchoalveolar lavage fluid levels similar to that of older patients (Wagener et al. 1998). The recovered rhDNase I was also enzymatically active. Enzymatic activity was directly correlated with rhDNase I concentrations in the sputum. Viscoelasticity was reduced in the recovered sputum, as well. Furthermore, results from scintigraphic studies in using twice daily $2.5 \mathrm{mg}$ of rhDNase I in CF patients suggested possible reductions in pulmonary

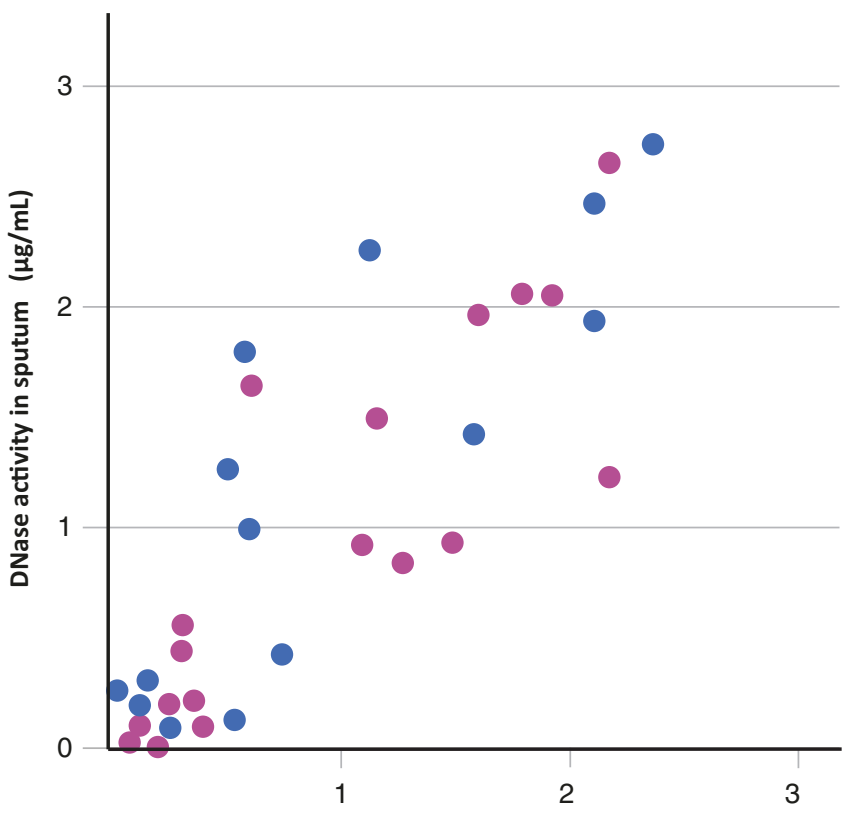

Amount of DNase I in sputum $(\mu \mathrm{g} / \mathrm{mL})$

Figure 22.8 Immunoreactive concentrations and enzymatic activity of rhDNase I in sputum following aerosol administration of either $10 \mathrm{mg}$ (purple filled circle) or $20 \mathrm{mg}$ (blue filled circle) rhDNase I to patients with cystic fibrosis. Each data point is a separate sample measured in duplicate

obstruction and increased rates of mucociliary sputum clearance from the inner zone of the lung compared to controls (Laube et al. 1996). This finding was not confirmed in a crossover design study using once-daily dosing, suggesting that improvement of mucociliary clearance may require higher doses (Robinson et al. 2000). Epidemiologic evaluation of patients changing from once-daily dosing to twice-daily and vice versa has also shown improvement in lung function and fewer pulmonary exacerbations on higher doses, although the clinical indication for a dose change is not clear (VanDevanter et al. 2018).

\section{Pharmacokinetics and Metabolism}

Nonclinical pharmacokinetic data in rats and monkeys suggest minimal systemic absorption of rhDNase I following aerosol inhalation of clinically equivalent doses. rhDNase I is cleared from the systemic circulation without any accumulation in tissues following acute exposure (Green 1994). Additionally, nonclinical metabolism studies suggest that the low rhDNase I concentrations present in serum following inhalation will be bound to binding proteins (Green 1994; Mohler et al. 1993). The low concentrations of endogenous DNase I normally present in serum and the low concentrations of rhDNase I in serum following inhalation are inactive due to the ionic com- 


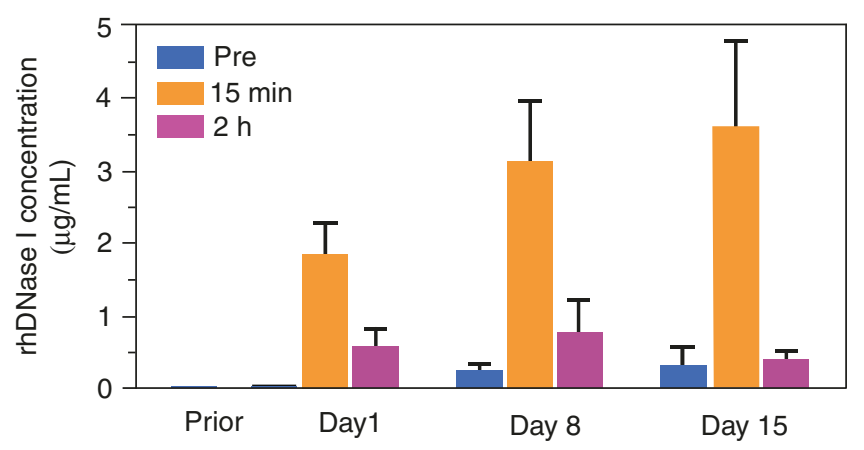

Figure $22.9 \square$ rhDNase I concentration in sputum following administration of $2.5 \mathrm{mg}$ of rhDNase I twice daily by inhalation to CF patients. The blue, orange, and purple bars represent concentrations at pre-dose, 15 min post-dose, and $2 \mathrm{~h}$ post-dose, respectively. The mean \pm SD is shown with $N=18$

position and presence of binding proteins in serum (Prince et al. 1998).

When $2.5 \mathrm{mg}$ of rhDNase I was administered twice daily by inhalation to $18 \mathrm{CF}$ patients, mean sputum concentrations of $2 \mu \mathrm{g} / \mathrm{mL}$ DNase I were measurable within 15 min after the first dose on Day 1 (Fig. 22.9). Mean sputum concentrations declined to an average of $0.6 \mu \mathrm{g} / \mathrm{mL} 2 \mathrm{~h}$ following inhalation. The peak rhDNase I concentration measured $2 \mathrm{~h}$ after inhalation on Days 8 and 15 increased to 3.0 and $3.6 \mu \mathrm{g} / \mathrm{mL}$, respectively. Sputum rhDNase I concentrations measured $6 \mathrm{~h}$ after inhalation on Days 8 and 15 were similar to Day 1. Predose trough concentrations of $0.3-0.4 \mu \mathrm{g} / \mathrm{mL}$ rhDNase I measured on Day 8 and Day 15 (sample taken approximately $12 \mathrm{~h}$ after the previous dose) were, however, higher than Day 1, suggesting possible modest accumulation of rhDNase I with repeated dosing. Inhalation of up to $10 \mathrm{mg}$ three times daily of rhDNase I by $4 \mathrm{CF}$ patients for 6 consecutive days did not result in significant elevation of serum concentrations of DNase above normal endogenous levels (Aitken et al. 1992; Hubbard et al. 1992). After administration of up to $2.5 \mathrm{mg}$ of rhDNase I twice daily for 6 months to 321 CF patients, no accumulation of serum DNase was noted (assay limit of detection is approximately $0.5 \mathrm{ng}$ DNase $/ \mathrm{mL}$ serum).

\section{PROTEIN MANUFACTURING AND FORMULATION}

rhDNase I is expressed in mammalian cell culture and purified to homogeneity using a variety of chromatographic steps. The development of the formulation of rhDNase I is especially important in that a suitable formulation is required to take into account protein stability, aerosolization properties, tonicity, and the sealed container for storage (Shire 1996). rhDNase I (Pulmozyme ${ }^{\circledR}$, dornase alfa) is manufactured by Genentech, Inc. and formulated as a sterile, clear, and colorless aqueous solution containing $1.0 \mathrm{mg} / \mathrm{mL}$ dor- nase alfa, $0.15 \mathrm{mg} / \mathrm{mL}$ calcium chloride dihydrate, and $8.77 \mathrm{mg} / \mathrm{mL}$ sodium chloride. The solution contains no preservative and has a nominal $\mathrm{pH}$ of 6.3. Pulmozyme ${ }^{\circledR}$ is administered by the inhalation of an aerosol mist produced by a compressed air-driven nebulizer system. Pulmozyme ${ }^{\circledR}$ is supplied as single-use ampoules, which deliver $2.5 \mathrm{~mL}$ of solution to the nebulizer.

The choice of formulation components was determined by a need to provide 1-2 years of stability and to meet additional requirements unique to aerosol delivery (Shire 1996). A simple colorimetric assay for rhDNase I activity was used to evaluate the stability of rhDNase I in various formulations (Sinicropi et al. 1994b). In order to avoid adverse pulmonary reactions, such as cough or bronchoconstriction, aerosols for local pulmonary delivery should be formulated as isotonic solutions with minimal or no buffer components and should maintain $\mathrm{pH}>5.0$. rhDNase I has an additional requirement for calcium to be present for optimal enzymatic activity. Limiting formulation components raised concerns about $\mathrm{pH}$ control, since protein stability and solubility can be highly pH-dependent. Fortunately, the protein itself provided sufficient buffering capacity at $1 \mathrm{mg} / \mathrm{mL}$ to maintain $\mathrm{pH}$ stability over the storage life of the product.

\section{DRUG DELIVERY}

The droplet or particle size of an aerosol is a critical factor in defining the site of deposition of the drug in the patient's airways (Gonda 1990). A distribution of particle or droplet size of $1-6 \mu \mathrm{m}$ is optimal for the uniform deposition of rhDNase I in the airways (Cipolla et al. 1994). Jet nebulizers are the simplest method of producing aerosols in the desired respirable range. However, recirculation of protein solutions under high shear rates in the nebulizer bowl can present risks to the integrity of the protein molecule. rhDNase I survived recirculation and high shear rates during the nebulization process with no apparent degradation in protein quality or enzymatic activity (Cipolla et al. 1994). Ultrasonic nebulizers produce greater heat than jet nebulizers and protein breakdown prevents their use with rhDNase I. Significant advances in nebulizer technology have occurred since the original approval of rhDNase I. Newer nebulizers using a vibrating, perforated membrane do not produce protein breakdown and provide more rapid and efficient delivery of particles in the respirable range (Scherer et al. 2011).

Approved jet nebulizers produce aerosol droplets in the respirable range $(1-6 \mu \mathrm{m})$ with a mass median aerodynamic diameter (MMAD) of 4-6 $\mu \mathrm{m}$. The delivery of rhDNase I with a device that produces smaller droplets leads to more peripheral deposition in the smaller airways and thereby improves efficacy (Geller 
et al. 1998). Results obtained in 749 CF patients with mild disease confirmed that patients randomized to the Sidestream nebulizer powered by the Mobil Aire Compressor $(\mathrm{MMAD}=2.1 \mu \mathrm{m})$ tended to have greater improvement in pulmonary function than patients using the Hudson $\mathrm{T}$ nebulizer with Pulmo-Aide Compressor $(\mathrm{MMAD}=4.9 \mu \mathrm{m})$. These results indicate that the efficacy of rhDNase I is dependent, in part, on the physical properties of the aerosol produced by the delivery system. Nebulizers with vibrating mesh technology (Pari eFlow ${ }^{\circledR}$ ) produce similarly small particles, suggesting these may result in further improved efficacy of rhDNase I. Furthermore, "smart" nebulizers are now available that coach the patient on taking a proper breath to improve delivery to the lower airways. Delivery of rhDNase I improves and lung function improves more when these nebulizers are used (Bakker et al. 2011). A randomized trial of efficacy and safety of dornase alfa delivered by the eRapid ${ }^{\circledR}$ nebulizer in CF patients showed comparable efficacy and safety, shorter nebulization times, and higher patient preference when compared to standard jet nebulizer systems such as the LC Plus (Sawicki et al. 2015).

\section{CLINICAL USE}

\section{Indication and Clinical Dosage}

rhDNase I (Pulmozyme ${ }^{\circledR}$, dornase alfa) is currently approved for use in CF patients, in conjunction with standard therapies, to reduce the frequency of respiratory infections requiring parenteral antibiotics and to improve pulmonary function (Fig. 22.1). The recommended dose for use in most CF patients is one $2.5 \mathrm{mg}$ dose inhaled daily.

\section{- Cystic Fibrosis}

rhDNase I was evaluated in a large, randomized, and placebo-controlled trial of clinically stable CF patients, 5 years of age or older, with baseline forced vital capacity (FVC) greater than or equal to $40 \%$ of predicted (Fuchs et al. 1994). All patients received additional standard therapies for CF. Patients were treated with placebo or $2.5 \mathrm{mg}$ of rhDNase I once or twice a day for 6 months. When compared to placebo, both once daily and twice daily doses of rhDNase I resulted in a $28-37 \%$ reduction in respiratory tract infections requiring use of parenteral antibiotics (Fig. 22.10). Within 8 days of the start of treatment with rhDNase I, mean forced expiratory volume in $1 \mathrm{~s}\left(\mathrm{FEV}_{1}\right)$ increased $7.9 \%$ in patients treated once a day and $9.0 \%$ in those treated twice a day compared to the baseline values. The mean $\mathrm{FEV}_{1}$ observed during long-term therapy increased $5.8 \%$ from baseline at the $2.5 \mathrm{mg}$ daily dose level and $5.6 \%$ from baseline at the $2.5 \mathrm{mg}$ twice daily dose level (Fig. 22.11). The risk of respiratory tract infection was reduced even

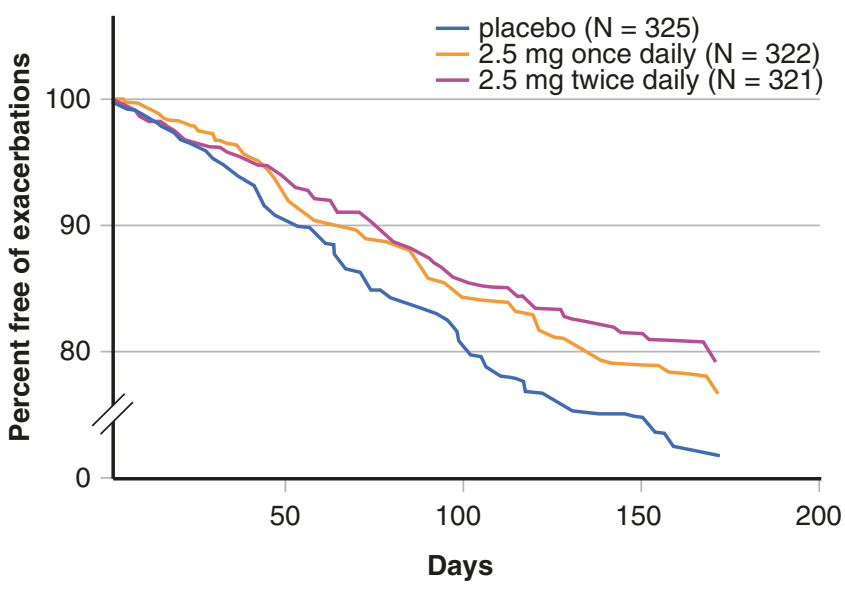

Figure 22.10 Proportion of patients free of exacerbations of respiratory symptoms requiring parenteral antibiotic therapy from a 24-week study

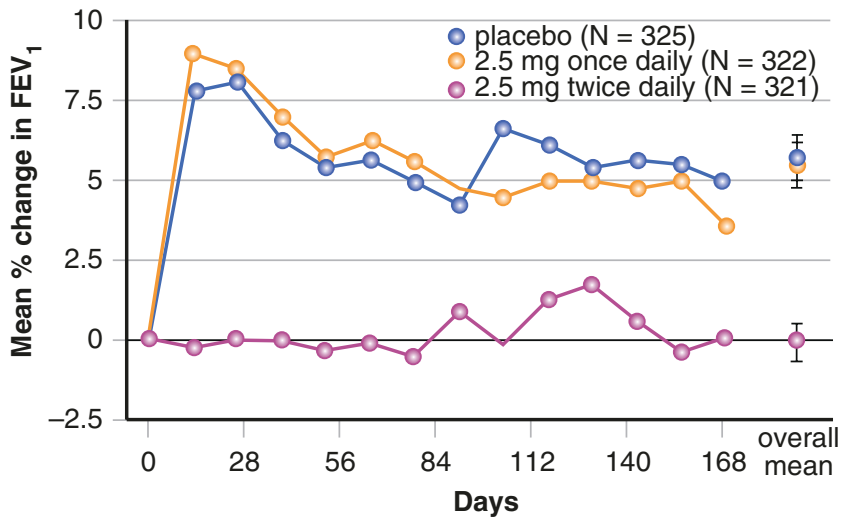

Figure $22.11 \square$ Mean percent change in $\mathrm{FEV}_{1}$ from baseline through a 24-week study

in patients whose pulmonary function $\left(\mathrm{FEV}_{1}\right)$ did not improve. This finding may be due to improved clearance of mucus from the small airways in the lung, which will have little effect on $\mathrm{FEV}_{1}$ (Shak 1995). Supporting this concept is the finding that rhDNase I improves the lung clearance index in 6-18-year-old CF patients with normal lung function (Amin et al. 2011). Alternatively, use of rhDNase I may be altering the neutrophilic inflammatory response that occurs early in the course of CF lung disease, similar to the use of other anti-inflammatory therapies (Konstan and Ratjen 2012). The administration of rhDNase I also lessened shortness of breath, increased the general perception of well-being, and reduced the severity of other cystic fibrosis-related symptoms. Based on these findings, the US Cystic Fibrosis Foundation, in their chronic therapy pulmonary guidelines, strongly recommends the use of rhDNase I in patients 6 years old and older with moderate to severe lung disease and recommends its use in patients with mild lung disease (Flume et al. 2007). 
The safety and deposition, but not efficacy, of rhDNase I has been studied in CF patients $<5$ years old ( 3 months to 5 years) since therapy may provide clinical benefit for young CF patients with mild disease (Wagener et al. 1998). After 2 weeks of daily administration of $2.5 \mathrm{mg}$ rhDNase I, levels of rhDNase I deposited in the lower airways were similar for children $<5$ years compared to a group of 5-10-year-olds. Moreover, rhDNase I was well tolerated in the younger age group with an adverse event frequency similar to that in the older age group. To further understand how rhDNase I might alter the progression of lung disease, children with mild CF related lung disease were treated for 2 years in a randomized controlled trial (Quan et al. 2001). Children with a mean age of 8.4 years and an FVC greater than $85 \%$ of predicted were treated once daily with either placebo or $2.5 \mathrm{mg}$ rhDNase I. After 96 weeks, lung function was significantly better in the treated group compared with placebo, particularly for tests measuring function of smaller airways. Respiratory exacerbations were also reduced in the treated group.

Clinical trials have indicated that rhDNase I therapy can be continued or initiated during an acute respiratory exacerbation (Wilmott et al. 1996). rhDNase I however does not produce a pulmonary function benefit when used short-term in the most severely ill CF patients (FVC less than $40 \%$ of predicted) (Shah et al. 1995; McCoy et al. 1996). Short-term dose ranging studies demonstrated that doses in excess of $2.5 \mathrm{mg}$ twice daily did not provide further significant improvement in $\mathrm{FEV}_{1}$ (Aitken et al. 1992; Hubbard et al. 1992; Ramsey et al. 1993). Patients who have received drug on a cyclical regimen (i.e., administration of rhDNase I $10 \mathrm{mg}$ twice daily for 14 days, followed by a 14-day washout period) showed rapid improvement in $\mathrm{FEV}_{1}$ with the initiation of rhDNase I and a return to baseline following withdrawal (Eisenberg et al. 1997). rhDNase I use improves quality of life as measured by the validated CFQ-R questionnaire (Rozov et al. 2010).

Concomitant therapy with rhDNase I and other standard CF therapies often show additive effects. The intermittent administration of aerosolized tobramycin was approved for use in CF patients with or without concomitant use of rhDNase I (Ramsey et al. 1999). Aerosolized tobramycin was well tolerated, enhanced pulmonary function, and decreased the density of P. aeruginosa in sputum. In combination with rhDNase I a larger treatment effect was noted but did not reach statistical significance. No differences in safety profile were observed following aerosolized tobramycin in patients that did or did not use rhDNase I. Chronic use of azithromycin has also been studied in CF patients chronically infected with $P$. aeruginosa (Saiman et al. 2005). Similar improvement in lung function and reduction in respiratory exacerbations was seen in patients receiving rhDNase I as those not, suggesting an additive, but not synergistic benefit of the two therapies used together. The combination of hypertonic saline therapy with chronic use of rhDNase I has similar additive benefits (Elkins et al. 2006), in agreement with the previously mentioned in vitro studies. Finally, combining ivacaftor, which potentiates chloride transport in CF patients with the G551D gene mutation, with chronic rhDNase I use produces an additive benefit in both improved lung function and reduced respiratory exacerbations (Ramsey et al. 2011). Notably, there was no evidence of a change in adverse events related to combination therapy in any of these studies.

Following FDA approval of rhDNase I in 1993, a large epidemiologic study of CF patients was initiated (the Epidemiologic Study of Cystic Fibrosis or ESCF), which continued until 2005 (Morgan et al. 1999). This study was designed to evaluate practice patterns in CF patients and has included data from over 24,000 patients. Recent analysis of ESCF data showed that chronic use of rhDNase I is associated with a decreased rate of decline in lung function overtime (Konstan et al. 2011). This reduced rate of decline in lung function is similar to findings with oral ibuprofen (Konstan et al. 1995, 2007) and inhaled corticosteroids (Ren et al. 2008), suggesting that there may be a long-term anti-inflammatory benefit with the use of rhDNase I. This potential anti-inflammatory effect is supported by a randomized trial in $105 \mathrm{CF}$ patients with mild lung disease $\left(\mathrm{FEV}_{1}>80 \%\right.$ predicted) (Paul et al. 2004). Based on an initial bronchoscopy and alveolar lavage, patients were divided into two groups, those without airway inflammation $(n=20)$ and those with. The patients with inflammation were then randomized to treatment with rhDNase I $(n=46)$ or not $(n=39)$. Follow-up bronchoscopy and lavage was performed at 18 and 36 months. In the patients treated with rhDNase I, there was no change in inflammation as measured by elastase and IL-8 levels and neutrophil number. Patients not treated with rhDNase I and patients who did not have inflammation at baseline all had worsening neutrophilic inflammation on follow-up. Although this study was not designed to evaluate the rate of lung function decline, treated patients dropped $\mathrm{FEV}_{1}$ by $1.99 \%$ predicted per year compared to a $3.26 \%$ predicted drop per year in the untreated subjects. Finally, rhDNase I is associated with a $15 \%$ reduction in the odds of subsequent year mortality in patients with CF (Sawicki et al. 2012).

\section{- Non-cystic Fibrosis Respiratory Disease}

Although originally considered beneficial for the treatment of non-CF related bronchiectasis (Wills et al. 1996), rhDNase I had no effect on pulmonary function or the frequency of respiratory exacerbations in a randomized controlled trial (O'Donnell et al. 1998). 
In another randomized controlled trial of rhDNase I, young children had shorter periods of ventilatory support following cardiac surgery when rhDNase I was instilled twice daily into the endotracheal tube (Riethmueller et al. 2006). Complicating atelectasis was less frequent in the treated group, consistent with numerous case reports suggesting that rhDNase I decreases, and can be used to treat, atelectasis when directly instilled into the airway (Hendriks et al. 2005). This effectiveness in treating atelectasis seems particularly true for newborns with lung disease requiring mechanical ventilation (MacKinnon et al. 2011; Dilmen et al. 2011; Fedakar et al. 2012; Altunhan et al. 2012). Limited benefit has been seen in children with asthma (Puterman and Weinberg 1997) although no benefit has been seen in adults (Silverman et al. 2012), consistent with the lack of neutrophil dominated inflammation in asthma. Finally, while there is increased free DNA in the secretions of infants with respiratory syncytial virus caused bronchiolitis, early suggestions of benefit (Nasr et al. 2001) have not translated into reduced hospitalization or the need for supplemental oxygen (Boogaard et al. 2007b).

\section{- Empyema and Para-Pneumonic Effusion}

In principle rhDNase I may be useful for treating any condition where high levels of extracellular DNA and associated viscoelastic properties are pathological. Pulmonary empyema involves the collection of purulent material in the pleural space and the use of rhDNase I instilled into the pleural space has been reviewed (Simpson et al. 2003; Corcoran et al. 2015). In one large, multicenter clinical trial for the treatment of empyema in adults, twice daily intrapleural administration over 3 days was evaluated in four groups: $5 \mathrm{mg}$ rhDNase, $10 \mathrm{mg}$ tissue plasminogen activator (t-PA), with the combination of both, and a double placebo. Patients receiving the combination therapy had improved fluid drainage and a reduced frequency of surgical referral (Rahman et al. 2011). Additional studies using similar doses have demonstrated similar clinical benefits in children, although determining when and if to perform surgery remains unclear (Piccolo et al. 2015; Gilbert and Gorden 2017). Importantly, it appears that using either t-PA or rhDNase 1 alone does not produce the benefit of combined therapy.

\section{Other Medical Conditions}

rhDNase I has also been instilled into the nasal sinuses after surgery for chronic infections (Cimmino et al. 2005; Raynor et al. 2000). While daily use over 28 days of nasal nebulized rhDNase I in patients with CF did not produce a significant change in the sinuses on MRI, there was a significant clinical improvement as measured by quality of life questionnaire (Mainz et al. 2011, 2014).
Children with otitis media develop chronic neutrophil inflammation and an associated increase in NETs. rhDNase I has been proposed for the management of chronic otitis disease in patients not responding well to antibiotics, although no significant clinical trials have been conducted (Thornton et al. 2013).

The effect of rhDNase I has been studied in a small group of advanced head and neck cancer patients with thick, tenacious upper airway secretions while receiving chemoradiationtherapy (Mittal et al. 2013). Preliminary results did not show a significant difference versus placebo in quality of life measures, but did show improvement in secondary endpoints of oropharyngeal secretions and DNA concentrations.

\section{Safety}

The administration of rhDNase I has not been associated with an increase in any major adverse events. Most adverse events were not more common with rhDNase I than with placebo treatment and probably reflect complications related to the underlying lung disease. Most events associated with dosing were mild, transient in nature, and did not require alterations in dosing. Observed symptoms included hoarseness, pharyngitis, laryngitis, rash, chest pain, and conjunctivitis. Within all the studies a small percentage (average $2-4 \%$ ) of patients treated with rhDNase I developed serum antibodies to rhDNase I. None of these patients developed anaphylaxis and the clinical significance of serum antibodies to rhDNase I is unknown. rhDNase I has also been associated with a slight increased risk of allergic bronchopulmonary aspergillosis in CF patients, although this most likely represents the chronic use of a wet nebulizer and not a complication of rhDNase I (Jubin et al. 2010).

\section{SUMMARY}

DNase I, a secreted human enzyme whose normal function is thought to be for digestion of extracellular DNA, has been developed as a safe and effective adjunctive agent in the treatment of pulmonary disease in cystic fibrosis patients. rhDNase I reduces the viscoelasticity and improves the transport properties of viscous mucus both in vitro and in vivo. Inhalation of aerosolized rhDNase I reduces the risk of infections requiring antibiotics and improves pulmonary function and the well-being of CF patients with mild to moderate disease. Studies also suggest that rhDNase I has benefit in infants and young children with $\mathrm{CF}$ and in patients with early disease who may have "normal" lung function. Additional studies may assess the usefulness of rhDNase I in early-stage CF pulmonary disease and other diseases where extracellular DNA and NETs may play a pathological role. 


\section{SELF-ASSESSMENT QUESTIONS}

\section{Questions}

1. Mutations of the CF gene result in abnormalities of the CF transmembrane conductance regulator protein. How do abnormalities of this protein lead to eventual lung damage?

2. How does rhDNase I result in improved pulmonary function in patients with cystic fibrosis?

3. rhDNase I is strongly recommended by the US Cystic Fibrosis Foundation for use in CF patients with moderate and severe lung disease. What other CF patients may benefit from using this therapy?

4. In addition to improving lung function in $\mathrm{CF}$ patients, what benefits have been demonstrated in clinical trials of rhDNase I?

5. What other medical conditions may benefit from treatment with rhDNase I?

6. Why should ultrasonic nebulizers not be used to administer rhDNase I? What other types of nebulizers might be effective for delivering rhDNase I?

\section{Answers}

1. Abnormal CFTR protein results in abnormal airway surface liquid, which leads to a vicious cycle of airway obstruction, infection, and inflammation. The chronic, excessive neutrophilic inflammation in the airway results in release of neutrophil elastase, oxidants, and extracellular DNA. These substances result in worsening obstruction and progressive airway damage.

2. rhDNase I cleaves extracellular DNA in the airway of CF patients, resulting in improved airway clearance of secretions. Additionally, rhDNase I may have anti-inflammatory properties, resulting in a slower progression of lung damage and reduced rate of decline in lung function. This antiinflammatory benefit is more likely present in patients with earlier, less severe lung disease.

3. rhDNase I is also recommended in CF patients over age 6 with mild lung disease. It has also been demonstrated as safe in younger patients, although efficacy has not been studied.

4. rhDNase I use decreases the frequency of respiratory exacerbations. rhDNase I also lessened shortness of breath, increased the general perception of well-being, and reduced the severity of other cystic fibrosis-related symptoms.

5. Although only approved by the FDA for treatment of lung disease in patients with $\mathrm{CF}$, controlled trials have also shown efficacy for treating empyema (in combination with t-PA) and sinus disease in patients with CF.
6. Ultrasonic nebulizers generate heat, which breaks down the protein in rhDNase I. Vibrating permeable membrane nebulizers and "smart" nebulizers do not damage the drug and may improve the effectiveness of rhDNase I.

\section{REFERENCES}

Ago H, Oda M, Takahashi M, Tsuge H, Ochi S, Katunuma N, Miyano M, Sakurai J (2006) Structural basis of the sphingomyelin phosphodiesterase activity in neutral sphingomyelinase from Bacillus cereus. J Biol Chem 281:16157-16167

Aitken ML, Burke W, McDonald G, Shak S, Montgomery AB, Smith A (1992) Recombinant human DNase inhalation in normal subjects and patients with cystic fibrosis. A phase 1 study. JAMA 267:1947-1951

Altunhan H, Annagür A, Pekcan S, Ors R, Koç H (2012) Comparing the efficacy of nebulizer recombinant human DNase and hypertonic saline as monotherapy and combined treatment in the treatment of persistent atelectasis in mechanically ventilated newborns. Pediatr Int 54:131-136

Amin R, Subbarao P, Lou W, Jabar A, Balkovec S, Jensen R, Kerrigan S, Gustafsson P, Ratjen F (2011) The effect of dornase alfa on ventilation in homogeneity in patients with cystic fibrosis. Eur Respir J 37:806-812

Andreeva A, Howorth D, Chandonia JM, Brenner SE, Hubbard TJ, Chothia C, Murzin AG (2008) Data growth and its impact on the SCOP database: new developments. Nucleic Acids Res 36:D419-D425

Apel F, Zychlinsky A, Kenny EF (2018) The role of neutrophil extracellular traps in rheumatic diseases. Nat Rev Rheumatol 14:467-475

Armstrong JB, White JC (1950) Liquefaction of viscous purulent exudates by deoxyribonuclease. Lancet 2:739-742

Bakker EM, Volpi S, Salonini E, van der Wiel-Kooij EC, Sintnicolaas CJJCM, Hop WCJ, Assael BM, Merkus PJFM, Tiddens HAWM (2011) Improved treatment response to dornase alfa in cystic fibrosis patients using controlled inhalation. Eur Respir J 38:1328-1335

Baranovskii AG, Buneva VN, Nevinsky GA (2004) Human deoxyribonucleases. Biochemistry (Mosc) 69:587-601

Bataillon V, Lhermitte M, Lafitte JJ, Pommery J, Roussel P (1992) The binding of amikacin to macromolecules from the sputum of patients suffering from respiratory diseases. J Antimicrob Chemother 29:499-508

Boogaard R, de Jongste JC, Merkus PJ (2007a) Pharmacotherapy of impaired mucociliary clearance in nonCF pediatric lung disease. A review of the literature. Pediatr Pulmonol 42:989-1001

Boogaard R, Hulsmann AR, van Veen L, Vaessen-Verberne AA, Yap YN, Sprij AJ, Brinkhorst G, Sibbles B, Hendriks T, Feith SW, Lincke CR, Brandsma AE, Brand PL, Hop WC, de Hoog M, Merkus PJ (2007b) Recombinant human deoxyribonuclease in infants with respiratory syncytial virus bronchiolitis. Chest 131:788-795 
Brinkmann V (2018) Neutrophil extracellular traps in the second decade. J Innate Immun 10:414-421

Brinkmann V, Reichard U, Goosmann C, Fauler B, Uhlemann Y, Weiss DS, Weinrauch Y, Zychlinsky A (2004) Neutrophil extracellular traps kill bacteria. Science 303:1532-1535

Campbell VW, Jackson DA (1980) The effect of divalent cations on the mode of action of DNase I. The initial reaction products produced from covalently closed circular DNA. J Biol Chem 255:3726-3735

Carpenter EP, Corbett A, Thomson H, Adacha J, Jensen K, Bergeron J, Kasampalidis I, Exley R, Winterbotham M, Tang C, Baldwin GS, Freemont P (2007) AP endonuclease paralogues with distinct activities in DNA repair and bacterial pathogenesis. EMBO J 26:1363-1372

Chen WJ, Liao TH (2006) Structure and function of bovine pancreatic deoxyribonuclease I. Protein Pept Lett 13:447-453

Chernick WS, Barbero GJ, Eichel HJ (1961) In vitro evaluation of effect of enzymes on tracheobronchial secretions from patients with cystic fibrosis. Pediatrics 27:589-596

Cimmino M, Nardone M, Cavaliere M, Plantulli A, Sepe A, Esposito V, Mazzarella G, Raia V (2005) Dornase alfa as postoperative therapy in cystic fibrosis sinonasal disease. Arch Otolaryngol Head Neck Surg 131:1097-1101

Cipolla D, Gonda I, Shire SJ (1994) Characterization of aerosols of human recombinant deoxyribonuclease I (rhDNase) generated by jet nebulizers. Pharm Res 11:491-498

Cools-Lartigue J, Spicer J, Najmeh S, Ferri L (2014) Neutrophil extracellular traps in cancer progression. Cell Mol Life Sci 71:4179-4194

Corcoran JP, Wrightson JM, Belcher E, DeCamp MM, FellerKopman D, Rahman NM (2015) Pleural infection: past, present, and future directions. Lancet Respir Med 3:563-577

Dasgupta B, King M (1996) Reduction in viscoelasticity in cystic fibrosis sputum in vitro using combined treatment with nacystelyn and rhDNase. Pediatr Pulmonol 22:161-166

Davis JC Jr, Manzi S, Yarboro C, Rairie J, McInnes I, Averthelyi D, Sinicropi D, Hale VG, Balow J, Austin H, Boumpas DT, Klippel JH (1999) Recombinant human DNase I (rhDNase) in patients with lupus nephritis. Lupus 8:68-76

Davoodian K, Ritchings BW, Ramphal R, Bubb MR (1997) Gelsolin activates DNase I in vitro and cystic fibrosis sputum. Biochemistry 36:9637-9641

Demers M, Wagner DD (2014) NETosis: a new factor in tumor progression and cancer-associated thrombosis. Semin Thromb Hemost 40:277-283

Desai M, Weller PH, Spencer DA (1995) Clinical benefit from nebulized human recombinant DNase in Kartagener's syndrome. Pediatr Pulmonol 20:307-308

Dilmen U, Karagol BS, Oguz SS (2011) Nebulized hypertonic saline and recombinant human DNase in the treatment of pulmonary atelectasis in newborns. Pediatr Int 53:328-331

Dlakic M (2000) Functionally unrelated signalling proteins contain a fold similar to $\mathrm{Mg}^{2+}$-dependent endonucleases. Trends Biochem Sci 25:272-273
Eisenberg JD, Aitken ML, Dorkin HL, Harwood IR, Ramsey BW, Schidlow DV, Wilmott RW, Wohl ME, Fuchs HJ, Christiansen DH, Smith AL (1997) Safety of repeated intermittent courses of aerosolized recombinant human deoxyribonuclease in patients with cystic fibrosis. J Pediatr 131:118-124

El Abiad NM, Clifton S, Nasr SZ (2007) Long-term use of nebulized human recombinant DNase I in two siblings with primary ciliary dyskinesia. Respir Med 101:2224-2226

Elkins MR, Robinson M, Rose BR, Harbour C, Moriarty CP, Marks GB, Belousova EG, Xuan W, Bye PT (2006) A controlled trial of long-term inhaled hypertonic saline in patients with cystic fibrosis. N Engl J Med 354: 229-240

Evans CJ, Aguilera RJ (2003) DNase II: genes, enzymes and function. Gene 322:1-15

Fedakar A, Aydogdu C, Fedakar A, Ugurlucan M, Bolu S, Iskender M (2012) Safety of recombinant human deoxyribonuclease as a rescue treatment for persistent atelectasis in newborns. Ann Saudi Med 32:131-136

Flume PA, O'Sullivan BP, Robinson KA, Goss CH, Mogayzel PJ Jr, Willey-Courand DB, Bujan J, Finder J, Lester M, Quittell L, Rosenblatt R, Vender RL, Hazle L, Sabadosa K, Marshall B (2007) Cystic fibrosis pulmonary guidelines: chronic medications for maintenance of lung health. Am J Respir Crit Care Med 176:957-969

Fuchs HJ, Borowitz DS, Christiansen DH, Morris EM, Nash ML, Ramsey BW, Rosenstein BJ, Smith AL, Wohl ME (1994) Effect of aerosolized recombinant human DNase on exacerbations of respiratory symptoms and on pulmonary function in patients with cystic fibrosis. N Engl J Med 331:637-642

Geller DE, Eigen H, Fiel SB, Clark A, Lamarre AP, Johnson CA, Konstan MW (1998) Effect of smaller droplet size of dornase alfa on lung function in mild cystic fibrosis. Pediatr Pulmonol 25:83-87

Gilbert CR, Gorden JA (2017) Use of intrapleural tissue plasminogen activator and deoxyribonuclease in pleural space infections: an update on alternative regimens. Curr Opin Pulm Med 23:371-375

Gonda I (1990) Aerosols for delivery of therapeutic and diagnostic agents to the respiratory tract. Crit Rev Ther Drug Carrier Syst 6:273-313

Gray RD, McCullagh BN, McCray PB (2015) NETs and CF lung disease: current status and future prospects. Antibiotics 4:62-75

Green JD (1994) Pharmaco-toxicological expert report Pulmozyme rhDNase Genentech, Inc. Hum Exp Toxicol 13:S1-S42

Gueroult M, Picot D, Abi-Ghanem J, Hartmann B, Baaden M (2010) How cations can assist DNase I in DNA binding and hydrolysis. PLoS Comput Biol 6:e1001000

Guggino WB, Stanton BA (2006) New insights into cystic fibrosis: molecular switches that regulate CFTR. Nat Rev Mol Cell Biol 7:426-436

Gupta S, Kaplan MJ (2016) The role of neutrophils and NETosis in autoimmune and renal diseases. Nat Rev Nephrol 12:402-413

Hakkim A, Fürnrohr BG, Amann K, Laube B, Abed UA, Brinkmann V, Herrmann M, Voll RE, Zychlinsky A 
(2010) Impairment of neutrophil extracellular trap degradation is associated with lupus nephritis. Proc Natl Acad Sci USA 107:9813-9818

Hawes MC, Wen F, Elquza E (2015) Extracellular DNA: a bridge to cancer. Cancer Res 75:4260-4264

Hendriks T, de Hoog M, Lequin MH, Devos AS, Merkus PJ (2005) DNase and atelectasis in non-cystic fibrosis pediatric patients. Crit Care 9:R351-R356

Hitchcock SE, Carisson L, Lindberg U (1976) Depolymeri zation of F-actin by deoxyribonuclease I. Cell 7:531-542

Honda M, Kubes P (2018) Neutrophils and neutrophil extracellular traps in the liver and gastrointestinal system. Nat Rev Gastroenterol Hepatol 15:206-221

Horton NC (2008) DNA nucleases. In: Rice PA, Correll CC (eds) Protein-nucleic acid interactions: structural biology. Royal Society of Chemistry Publishing, Cambridge, pp 333-363

Hubbard RC, McElvaney NG, Birrer P, Shak S, Robinson WW, Jolley C, Wu M, Chernick MS, Crystal RG (1992) A preliminary study of aerosolized recombinant human deoxyribonuclease I in the treatment of cystic fibrosis. N Engl J Med 326:812-815

Jiménez-Alcázar M, Kim N, Fuchs TA (2017a) Circulating extracellular DNA: cause or consequence of thrombosis? Semin Thromb Hemost 243:553-561

Jiménez-Alcázar M, Rangaswamy C, Panda R, Bitterling J, Simsek YJ, Long AT, Bilyy R, Krenn V, Renné C, Renné T, Kluge S, Panzer U, Mizuta R, Mannherz HG, Kitamura D, Herrmann M, Napirei M, Fuchs TA (2017b) Host DNases prevent vascular occlusion by neutrophil extracellular traps. Science 358: 1202-1206

Jorch SK, Kubes P (2017) An emerging role for neutrophil extracellular traps in noninfectious disease. Nat Med 23:279-287

Jubin V, Ranque S, Le bel NS, Sarles J, Dubus J-C (2010) Risk factors for Aspergillus colonization and allergic bronchopulmonary aspergillosis in children with cystic fibrosis. Pediatr Pulmonol 45:764-771

Kabsch W, Mannherz HG, Suck D, Pai EF, Holmes KC (1990) Atomic structure of the actin: DNase I complex. Nature 347:37-44

Kaplan JB, LoVetri K, Cardona ST, Madhyastha S, Sadovskaya I, Jabbouri S, Izano EA (2012) Recombinant human DNase I decreases biofilm and increases antimicrobial susceptibility in Staphylococci. J Antibiot (Tokyo) 65:73-77

Kerem B, Rommens JM, Buchanan JA, Markiewicz D, Cox TK, Chakravarti A, Buchwald M, Tsui LC (1989) Identification of the cystic fibrosis gene: genetic analysis. Science 245:1073-1080

Keyel PA (2017) Dnases in health and disease. Dev Biol 429:1-11

King M, Dasgupta B, Tomkiewicz RP, Brown NE (1997) Rheology of cystic fibrosis sputum after in vitro treatment with hypertonic saline alone and in combination with recombinant human deoxyribonuclease I. Am J Respir Crit Care Med 156:173-177

Kominato Y, Ueki M, Iida R, Kawai Y, Nakajima T, Makita C, Itoi M, Tajima Y, Kishi K, Yasuda T (2006) Characterization of human deoxyribonuclease I gene (DNASE1) promoters reveals the utilization of two tran- scription-starting exons and the involvement of Sp1 in its transcriptional regulation. FEBS J 273:3094-3105

Konstan MW, Ratjen F (2012) Effect of dornase alfa on inflammation and lung function: potential role in the early treatment of cystic fibrosis. J Cyst Fibros 11:78-83

Konstan MW, Byard PJ, Hoppel CL, Davis PB (1995) Effect of high-dose ibuprofen in patients with cystic fibrosis. $\mathrm{N}$ Engl J Med 332:848-854

Konstan MW, Schluchter MD, Xue W, Davis PB (2007) Clinical use of Ibuprofen is associated with slower $\mathrm{FEV}_{1}$ decline in children with cystic fibrosis. Am J Respir Crit Care Med 176:1084-1089

Konstan MW, VanDevanter DR, Rasouliyan L, Pasta DJ, Yegin A, Morgan WJ, Wagener JS (2010) Trends in the use of routine therapies in cystic fibrosis: 1995-2005. Pediatr Pulmonol 45:1167-1172

Konstan MW, Wagener JS, Pasta DJ, Millar SJ, Jacobs JR, Yegin A, Morgan WJ (2011) Clinical use of dornase alfa is associated with a slower rate of $\mathrm{FEV}_{1}$ decline in cystic fibrosis. Pediatr Pulmonol 46:545-553

Lachmann PJ (2003) Lupus and desoxyribonuclease. Lupus 12:202-206

Laskowski M Sr (1971) Deoxyribonuclease I. In: Boyer PD (ed) The enzymes, vol 4, 3rd edn. Academic, New York, pp 289-311

Laube BL, Auci RM, Shields DE, Christiansen DH, Lucas MK, Fuchs HJ, Rosenstein BJ (1996) Effect of rhDNase on airflow obstruction and mucociliary clearance in cystic fibrosis. Am J Respir Crit Care Med 153:752-760

Law SM, Gray RD (2017) Neutrophil extracellular traps and the dysfunctional innate immune response of cystic fibrosis lung disease: a review. J Inflamm 14:29

Lazarides E, Lindberg U (1974) Actin is the naturally occurring inhibitor of deoxyribonuclease I. Proc Natl Acad Sci USA 71:4742-4746

Lazarus RA (2002) Human deoxyribonucleases. In: Creighton TE (ed) Wiley encyclopedia of molecular medicine. Wiley, New York, pp 1025-1028

Lieberman J (1962) Enzymatic dissolution of pulmonary secretions. An in vitro study of sputum from patients with cystic fibrosis of pancreas. Am J Dis Child 104:342-348

Lieberman J (1968) Dornase aerosol effect on sputum viscosity in cases of cystic fibrosis. JAMA 205:312-313

Lood C, Blanco LP, Purmalek MM, Carmona-Rivera C, De Ravin SS, Smith CK, Malech HL, Ledbetter JA, Elkon KB, Kaplan MJ (2016) Neutrophil extracellular traps enriched in oxidized mitochondrial DNA are interferogenic and contribute to lupus-like disease. Nat Med 22:146-153

MacKinnon R, Wheeler KI, Sokol J (2011) Endotracheal DNase for atelectasis in ventilated neonates. J Perinatol 31:799-801

Mainz JG, Schiller I, Ritschel C, Mentzel H-J, Riethmuller J, Koitschev A, Schneider G, Beck JF, Wiedemann B (2011) Sinonasal inhalation of dornase alfa in CF: a doubleblind placebo-controlled cross-over pilot trial. Auris Nasus Larynx 38:220-227

Mainz JG, Schien C, Schiller I, Schädlich K, Koitschev A, Koitschev C, Riethmüller J, Graepler-Mainka U, Wiedemann B, Beck JF (2014) Sinonasal inhalation of 
dornase alfa administered by vibrating aerosol to cystic fibrosis patients: a double-blind placebo-controlled cross-over trial. J Cyst Fibros 13:461-470

Martinod K, Wagner DD (2014) Thrombosis: tangled up in NETs. Blood 123(18):2768-2776

Matthews LW, Specter S, Lemm J, Potter JL (1963) The overall chemical composition of pulmonary secretions from patients with cystic fibrosis, bronchiectasis and laryngectomy. Am Rev Respir Dis 88:119-204

McCoy K, Hamilton S, Johnson C (1996) Effects of 12-week administration of dornase alfa in patients with advanced cystic fibrosis lung disease. Chest 110:889-895

Merza M, Hartman H, Rahman M, Hwaiz R, Zhang E, Renström E, Luo L, Mörgelin M, Regner S, Thorlacius H (2015) Neutrophil extracellular traps induce trypsin activation, inflammation, and tissue damage in mice with severe acute pancreatitis. Gastroenterology 149:1920-1931

Mittal BB, Wang E, Sejpal S, Agulnik M, Mittal A, Harris K (2013) Effect of recombinant human deoxyribonuclease on oropharyngeal secretions in patients with headand-neck cancers treated with radiochemotherapy. Int J Radiat Oncol Biol Phys 87:282-289

Mohler M, Cook J, Lewis D, Moore J, Sinicropi D, Championsmith A, Ferraiolo B, Mordenti J (1993) Altered pharmacokinetics of recombinant human deoxyribonuclease in rats due to the presence of a binding protein. Drug Metab Dispos 21:71-75

Mol CD, Izumi T, Mitra S, Tainer JA (2000) DNA-bound structures and mutants reveal abasic DNA binding by APE1 and DNA repair coordination. Nature 403:451-456

Moore S (1981) Pancreatic DNase. In: Boyer PD (ed) The enzymes, vol 14, 3rd edn. Academic, New York, pp 281-296

Morgan WJ, Butler SM, Johnson CA, Colin AA, FitzSimmons SC, Geller DE, Konstan MW, Light MJ, Rabin HR, Regelmann WE, Schidlow DV, Stokes DC, Wohl ME, Kaplowitz H, Wyatt MM, Stryker S (1999) Epidemiologic study of cystic fibrosis: design and implementation of a prospective, multicenter, observational study of patients with cystic fibrosis in the U.S. and Canada. Pediatr Pulmonol 28:231-241

ten Berge M, Brinkhorst G, Kroon AA, de Jongste JC (1999) DNase treatment in primary ciliary dyskinesiaassessment by nocturnal pulse oximetry. Pediatr Pulmonol 27:59-61

Nasr SZ, Strouse PJ, Soskolne E, Maxvold NJ, Garver KA, Rubin BK, Moler FW (2001) Efficacy of recombinant human deoxyribonuclease I in the hospital management of respiratory syncytial virus bronchiolitis. Chest 120:203-208

O’Donnell AE, Barker AF, Ilowite JS, Fick RB (1998) Treatment of idiopathic bronchiectasis with aerosolized recombinant human DNase I. rhDNase Study Group. Chest 113:1329-1334

Pan CQ, Lazarus RA (1997) Engineering hyperactive variants of human deoxyribonuclease I by altering its functional mechanism. Biochemistry 36:6624-6632
Pan CQ, Lazarus RA (1999) $\mathrm{Ca}^{2+}$-dependent activity of human DNase I and its hyperactive variants. Protein Sci 8:1780-1788

Pan CQ, Ulmer JS, Herzka A, Lazarus RA (1998a) Mutational analysis of human DNase I at the DNA binding interface: implications for DNA recognition, catalysis, and metal ion dependence. Protein Sci 7:628-636

Pan CQ, Dodge TH, Baker DL, Prince WS, Sinicropi DV, Lazarus RA (1998b) Improved potency of hyperactive and actin-resistant human DNase I variants for treatment of cystic fibrosis and systemic lupus erythematosus. J Biol Chem 273:18374-18381

Pan CQ, Sinicropi DV, Lazarus RA (2001) Engineered properties and assays for human DNase I mutants. Methods Mol Biol 160:309-321

Park J, Wysocki RW, Amoozgar Z, Maiorino L, Fein MR, Jorns J, Schott AF, Kinugasa-Katayama Y, Lee Y, Won NH, Nakasone ES, Hearn SA, Küttner V, Qiu J, Almeida AS, Perurena N, Kessenbrock K, Goldberg MS, Egeblad M (2016) Cancer cells induce metastasis-supporting neutrophil extracellular DNA traps. Sci Transl Med 8:361ra138

Parsiegla G, Noguere C, Santell L, Lazarus RA, Bourne Y (2012) The structure of human DNase I bound to magnesium and phosphate ions points to a catalytic mechanism common to members of the DNase I-like superfamily. Biochemistry 51:10250-10258

Paul K, Rietschel E, Ballmann M, Griese M, Worlitzsch D, Shute J, Chen C, Schink T, Döring G, van Koningsbruggen S, Wahn U, Ratjen F (2004) Effect of treatment with dornase alpha on airway inflammation in patients with cystic fibrosis. Am J Respir Crit Care Med 169:719-725

Piccolo F, Popowicz N, Wong D, Lee YC (2015) Intrapleural tissue plasminogen activator and deoxyribonuclease therapy for pleural infection. J Thorac Dis 7:999-1008

Potter JL, Specter S, Matthews LW, Lemm J (1969) Studies on pulmonary secretions. 3. The nucleic acids in whole pulmonary secretions from patients with cystic fibrosis bronchiectasis and laryngectomy. Am Rev Respir Dis 99:909-915

Prince WS, Baker DL, Dodge AH, Ahmed AE, Chestnut RW, Sinicropi DV (1998) Pharmacodynamics of recombinant human DNase I in serum. Clin Exp Immunol 113:289-296

Puterman AS, Weinberg EG (1997) rhDNase in acute asthma. Pediatr Pulmonol 23:316-317

Quan JM, Tiddens HA, Sy JP, McKenzie SG, Montgomery MD, Robinson PJ, Wohl ME, Konstan MW (2001) A two-year randomized, placebo-controlled trial of dornase alfa in young patients with cystic fibrosis with mild lung function abnormalities. J Pediatr 139:813-820

Rahman NM, Maskell NA, West A, Teoh R, Arnold A, Mackinlay C, Peckham D, Davies CW, Ali N, Kinnear W, Bentley A, Kahan BC, Wrightson JM, Davies HE, Hooper CE, Lee YC, Hedley EL, Crosthwaite N, Choo L, Helm EJ, Gleeson FV, Nunn AJ, Davies RJ (2011) Intrapleural use of tissue plasminogen activator and DNase in pleural infection. N Engl J Med 365:518-526 
Ramphal R, Lhermitte M, Filliat M, Roussel P (1988) The binding of anti-pseudomonal antibiotics to macromolecules from cystic fibrosis sputum. J Antimicrob Chemother 22:483-490

Ramsey BW, Astley SJ, Aitken ML, Burke W, Colin AA, Dorkin HL, Eisenberg JD, Gibson RL, Harwood IR, Schidlow DV, Wilmott RW, Wohl ME, Meyerson LJ, Shak S, Fuchs H, Smith AL (1993) Efficacy and safety of short-term administration of aerosolized recombinant human deoxyribonuclease in patients with cystic fibrosis. Am Rev Respir Dis 148:145-151

Ramsey BW, Pepe MS, Quan JM, Otto KL, Montgomery $\mathrm{AB}$, Williams-Warren J, Vasiljev KM, Borowitz D, Bowman CM, Marshall BC, Marshall S, Smith AL (1999) Intermittent administration of inhaled tobramycin in patients with cystic fibrosis. $\mathrm{N}$ Engl J Med 340:23-30

Ramsey BW, Davies J, NG ME, Tullis E, Bell SC, Dřevínek P, Griese M, EF MK, Wainwright CE, Konstan MW, Moss R, Ratjen F, Sermet-Gaudelus I, Rowe SM, Dong Q, Rodriguez S, Yen K, Ordoñez C, Elborn JS, VX08770-102 Study Group (2011) A CFTR potentiator in patients with cystic fibrosis and the G551D mutation. New Engl J Med 365:1663-1672

Raskin P (1968) Bronchospasm after inhalation of pancreatic dornase. Am Rev Respir Dis 98:697-698

Raynor EM, Butler A, Guill M, Bent JP 3rd (2000) Nasally inhaled dornase alfa in the postoperative management of chronic sinusitis due to cystic fibrosis. Arch Otolaryngol Head Neck Surg 126:581-583

Ren CL, Pasta DJ, Rasouliyan L, Wagener JS, Konstan MW, Morgan WJ (2008) Relationship between inhaled corticosteroid therapy and rate of lung function decline in children with cystic fibrosis. J Pediatr 153:746-751

Riethmueller J, Borth-Bruhns T, Kumpf M, Vonthein R, Wiskirchen J, Stern M, Hofbeck M, Baden W (2006) Recombinant human deoxyribonuclease shortens ventilation time in young, mechanically ventilated children. Pediatr Pulmonol 41:61-66

Riordan JR, Rommens JM, Kerem B, Alon N, Rozmahel R, Grzelczak Z, Zielenski J, Lok S, Plavsic N, Chou JL, Drumm ML, Iannuzzi MC, Collins FS, Tsui LC (1989) Identification of the cystic fibrosis gene: cloning and characterization of complementary DNA. Science 245:1066-1073

Robinson M, Hemming AL, Moriarty C, Eberl S, Bye PT (2000) Effect of a short course of rhDNase on cough and mucociliary clearance in patients with cystic fibrosis. Pediatr Pulmonol 30:16-24

Rozov T, de Oliveira VZ, Santana MA, Adde FV, Mendes RH, Paschoal IA, Reis FJC, Higa LYS, de Castro Toledo AC Jr, Pahl M (2010) Dornase alfa improves the healthrelated quality of life among Brazilian patients with cystic fibrosis-a one-year prospective study. Pediatr Pulmonol 45:874-882

Saiman L, Mayer-Hamblett N, Campbell P, Marshall BC (2005) Heterogeneity of treatment response to azithromycin in patients with cystic fibrosis. Am J Respir Crit Care Med 172:1008-1012
Sanders NN, Franckx H, De Boeck K, Haustraete J, De Smedt SC, Demeester J (2006) Role of magnesium in the failure of rhDNase therapy in patients with cystic fibrosis. Thorax 61:962-968

Sawicki GS, Signorovitch JE, Zhang J, Latremouille-Viau D, von Wartburg M, Wu EQ, Shi L (2012) Reduced mortality in cystic fibrosis patients treated with tobramycin inhalation solution. Pediatr Pulmonol 47:44-52

Sawicki GS, Chou W, Raimundo K, Trzaskoma B, Konstan MW (2015) Randomized trial of efficacy and safety of dornase alfa delivered by eRapid nebulizer in cystic fibrosis patients. J Cyst Fibros 14:777-783

Scala M, Hoy D, Bautista M, Palafoutas JJ, Abubakar K (2017) Pilot study of dornase alfa (Pulmozyme) therapy for acquired ventilator-associated infection in preterm infants. Pediatr Pulmonol 52:787-791

Scherer T, Geller DE, Owyang L, Tservistas M, Keller M, Boden N, Kesser KC, Shire SJ (2011) A technical feasibility study of dornase alfa delivery with eFlow vibrating membrane nebulizers: aerosol characteristics and physicochemical stability. J Pharm Sci 100:98-109

Shah PI, Bush A, Canny GJ, Colin AA, Fuchs HJ, Geddes DM, Johnson CA, Light MC, Scott SF, Tullis DE, De Vault A, Wohl ME, Hodson ME (1995) Recombinant human DNase I in cystic fibrosis patients with severe pulmonary disease: a short-term, double-blind study followed by six months open-label treatment. Eur Respir J 8:954-958

Shak S (1995) Aerosolized recombinant human DNase I for the treatment of cystic fibrosis. Chest 107:65S-70S

Shak S, Capon DJ, Hellmiss R, Marsters SA, Baker CL (1990) Recombinant human DNase I reduces the viscosity of cystic fibrosis sputum. Proc Natl Acad Sci USA 87:9188-9192

Shiokawa D, Tanuma S (2001) Characterization of human DNase I family endonucleases and activation of DNase gamma during apoptosis. Biochemistry 40:143-152

Shire SJ (1996) Stability characterization and formulation development of recombinant human deoxyribonuclease I [Pulmozyme, (dornase alfa)]. In: Pearlman R, Wang YJ (eds) Pharmaceutical biotechnology: formulation, characterization and stability of protein drugs, vol 9. Plenum Press, New York, pp 393-426

Silverman RA, Foley F, Dalipi R, Kline M, Lesser M (2012) The use of rhDNAse in severely ill, non-intubated adult asthmatics refractory to bronchodilators: a pilot study. Respir Med 106:1096-1102

Simpson G, Roomes D, Reeves B (2003) Successful treatment of empyema thoracis with human recombinant deoxyribonuclease. Thorax 58:365-366

Sinicropi DV, Lazarus RA (2001) Assays for human DNase I activity in biological matrices. Methods Mol Biol 160:325-333

Sinicropi DV, Prince WS, Lofgren JA, Williams M, Lucas M, DeVault A (1994a) Sputum pharmacodynamics and pharmacokinetics of recombinant human DNase I in cystic fibrosis. Am J Respir Crit Care Med 149:A671

Sinicropi D, Baker DL, Prince WS, Shiffer K, Shak S (1994b) Colorimetric determination of DNase I activity with a DNA-methyl green substrate. Anal Biochem 222:351-358 
Suck D (1994) DNA recognition by DNase I. J Mol Recognit 7:65-70

Suri R (2005) The use of human deoxyribonuclease (rhDNase) in the management of cystic fibrosis. BioDrugs 19:135-144

Thornton RB, Wiertsema SP, Kirkham LS, Rigby PJ, Vijayasekaran S, Coates HL, Richmond PC (2013) Neutrophil extracellular traps and bacterial biofilms in middle ear effusion of children with recurrent acute otitis media-a potential treatment target. PLoS One 8:e53837

Ulmer JS, Herzka A, Toy KJ, Baker DL, Dodge AH, Sinicropi D, Shak S, Lazarus RA (1996) Engineering actinresistant human DNase I for treatment of cystic fibrosis. Proc Natl Acad Sci USA 93:8225-8229

VanDevanter DR, Craib ML, Pasta DJ, Millar SJ, Morgan WJ, Konstan MW (2018) Cystic fibrosis clinical characteristics asssoiciated with dornase alfa treatment regimen change. Pediatr Pulmonol 53:43-49

Vasconcellos CA, Allen PG, Wohl ME, Drazen JM, Janmey PA, Stossel TP (1994) Reduction in viscosity of cystic fibrosis sputum in vitro by gelsolin. Science 263:969-971

Wagener JS, Kupfer O (2012) Dornase alfa (pulmozyme). Curr Opin Pulm Med 18:609-614

Wagener JS, Rock MJ, McCubbin MM, Hamilton SD, Johnson CA, Ahrens RC (1998) Aerosol delivery and safety of recombinant human deoxyribonuclease in young children with cystic fibrosis: a bronchoscopic study. J Pediatr 133:486-491

Wang H, Morita M, Yang X, Suzuki T, Yang W, Wang J, Ito K, Wang Q, Zhao C, Bartlam M, Yamamoto T, Rao Z
(2010) Crystal structure of the human CNOT6L nuclease domain reveals strict poly(A) substrate specificity. EMBO J 29:2566-2576

Widlak P, Garrard WT (2005) Discovery, regulation, and action of the major apoptotic nucleases DFF40/CAD and endonuclease G. J Cell Biochem 94:1078-1087

Wills PJ, Wodehouse T, Corkery K, Mallon K, Wilson R, Cole PJ (1996) Short-term recombinant human DNase in bronchiectasis. Effect on clinical state and in vitro sputum transportability. Am J Respir Crit Care Med 154:413-417

Wilmott RW, Amin RS, Colin AA, DeVault A, Dozor AJ, Eigen H, Johnson C, Lester LA, McCoy K, McKean LP, Moss R, Nash ML, Jue CP, Regelmann W, Stokes DC, Fuchs HJ (1996) Aerosolized recombinant human DNase in hospitalized cystic fibrosis patients with acute pulmonary exacerbations. Am J Respir Crit Care Med 153:1914-1917

Wolf E, Frenz J, Suck D (1995) Structure of human pancreatic DNase I at 2.2 Å resolution. Protein Eng 8:79

Wong SL, Demers M, Martinod K, Gallant M, Wang Y, Goldfine AB, Kahn CR, Wagner DD (2015) Diabetes primes neutrophils to undergo NETosis, which impairs wound healing. Nat Med 21:815-819

Yang W (2011) Nucleases: diversity of structure, function and mechanism. Q Rev Biophys 44:1-93

Zahm JM, Girod de Bentzmann S, Deneuville E, PerrotMinnot C, Dabadie A, Pennaforte F, Roussey M, Shak S, Puchelle E (1995) Dose-dependent in vitro effect of recombinant human DNase on rheological and transport properties of cystic fibrosis respiratory mucus. Eur Respir J 8:381-386 